Araştırma Makalesi • Research Article

\title{
Siyasal Pazarlamada Adayların Marka Kişilik Boyutları*
}

\section{Brand Personality Dimensions of Candidates in Political Marketing**}

\author{
Dilvin ER CANTÜRK ${ }^{\mathrm{a}}$ Polat CAN ${ }^{\mathrm{b}}$ \\ a Doktora Öğrencisi, Anadolu Üniversitesi, Eskișehir, Türkiye \\ dilwiner@outlook.com \\ ORCID: 0000-0003-4423-8793 \\ bDr.Öğr.Üyesi, Uşak Üniversitesi, Uşak, Türkiye \\ polat.can@usak.edu.tr \\ ORCID:
}

\section{MAKALE BILGISİ}

\section{Makale Geçmişi:}

Başvuru tarihi: 13.08 .2020

Düzeltme tarihi: 07.12.2020

Kabul tarihi: 21.12.2020

\section{Anahtar Kelimeler:}

Siyasal Pazarlama,

Marka Kişiliği,

Siyasal Marka,

\begin{abstract}
ÖZ
Beklenti ve gereksinimlerin hızla değiştiği ve arttığı küreselleşen dünyada, marka olgusu toplumsal hayatın her alanında varlığını ve önemini hissettirmektedir. Bu bağlamda siyaset bilimi ise etkili ve başarılı olabilmek için pazarlama disiplininden yoğun bir şekilde yararlanmaktadır. Bu durum siyasal pazarlamada insan unsurunu siyasi yaşamın parçası olmasına yol açmaktadır. Siyasal süreç propaganda ile başlamış iletişim ve profesyonelleşme ile gücünün daha da pekiştirmektedir. Pazarlama uygulamaları kampanyalarda gün geçtikçe önemini arttırırken marka kavramı da siyasal pazarlama alanında önemini arttırmaktadır. Siyasi hayattaki adayların birer marka olarak kabul edilmesiyle birlikte marka kişilikleri incelenmesi ve marka kişilik boyutlarının belirlenme ihtiyacını ortaya çıkarmıştır. Buradan hareketle, 2019 yerel seçimlerinde Uşak Belediye başkan adaylarının marka kişilik özelliklerini belirlemek amaçlanmıştır. Bu amaç doğrultusunda, 18 yaş ve üzeri Uşak il merkezinde yaşayan ve kararsız olan seçmenlere yüz yüze anket uygulanmıştır. Sonuçlar, SPSS 23.0 ve AMOS 23 istatistik programları ile analiz edilmiştir. Elde edilen veriler 1şığında, marka kişilik ölçeğine göre belediye başkan adaylarına yönelik algı ve tutumlar arasında anlamlı bir etki olduğu belirlenmiştir.
\end{abstract}

\begin{tabular}{l} 
ARTICLE INFO \\
\hline Article history: \\
Received: 1.08 .2020 \\
Received in revised form: 07.12 .2020 \\
Accepted: 21.12 .2020 \\
\hline
\end{tabular}

Keywords:

Political Marketing,

Brand Personality

Political Brand

\section{ABSTRACT}

In the globalizing world where expectations and needs change and increase rapidly, the brand phenomenon makes its presence and importance felt in all areas of social life. In this context, political science makes extensive use of the marketing discipline in order to be effective and successful. This situation causes the human element to become a part of political life in political marketing. The political process started with propaganda and strengthens its power with communication and professionalization. While marketing practices increase their importance in campaigns day by day, the concept of brand increases its importance in the field of political marketing. With the acceptance of candidates in political life as brands, the need to examine brand personalities and determine brand personality dimensions has emerged. Based on this, it was aimed to determine the brand personality characteristics of Uşak mayor candidates in the 2019 local elections. For this purpose, a face-to-face questionnaire was applied to floating voters aged 18 and over living in the city center of Uşak. The results were analyzed by SPSS 23.0 and AMOS 23 statistics programs. In the light of the data obtained, it was determined that the brand personality traits of the mayor candidates were different according to the brand personality scale.

${ }^{*}$ Bu çalışma, Dılvin ER CANTÜRK tarafından Uşak Üniversitesi Lisansüstü Eğitim Enstitüsünde hazırlanan ve danışmanlığını Dr. Öğr. Üyesi Polat CAN'ın yaptığı ve kabul edilen yüksek lisans tezinden türetilmiştir.

** DOI: $10.46442 /$ intjcss.779966

${ }^{* * *}$ Sorumlu Yazar: Dilvin ER CANTÜRK, dilwiner@ outlook.com 


\section{Atıf Bilgisi / Reference Information}

Cantürk, E.D. ve CAN, P. (2020). Siyasal Pazarlamada Adayların Marka Kişilik Boyutları. Uluslararası Kültürel ve Sosyal Araştırmalar Dergisi (UKSAD), 6 (2), Kış, s. 531-551.

\section{Giriș}

Demokratik toplumlarda siyasal yaşama ortak olmanın iki temel unsuru seçimler ve siyasal partilerdir. Örgütlü olarak halk adına karar vermek ve iktidar gücünü kullanması siyasal partilere; oy kullanma, siyasi adayların belirlenmesi ve demokratik ortamın gelişmesi de seçimlere önem kazandırmaktadır. Diğer taraftan pazarlama da siyaset gibi birey ile ilgili olan disiplinlerden biridir. Pazarlama da gereksinimlerin uygun şekilde karşılanması kısa süreli bir çalışma ile sağlanırken siyasette bu beklenti ve gereksinimleri karşılamak uzun bir süreç içerisinde gerçekleşmektedir. Pazarlama, ihtiyacın belirlenmesinden itibaren onları verimli şekilde karşılayıp son aşamada tüketici tatminini esas alarak belli hedeflere ulaşmayı amaçlayan süreçler bütünüdür.

Günümüzde kitle iletişim araçlarında artarak devam eden değişim ve mesaj yoğunluğu birçok alanda olduğu gibi siyasal pazarlamanın da öneminin artmasına olanak sağlamaktadır. Siyasal pazarlama sürecinde tüketiciyi yani seçmeni etki altına almak ve tercih edilmeyi sağlamak gün geçtikçe zorlaşmakta dolayısıyla farklı tekniklerin kullanılması, örneğin; seçmenin beklentilerini bilmek ve buna göre programlar hazırlamak gibi unsurlar kaçınılmaz olmaktadır. Siyasal pazarlama kavramının, Amerika Birleşik Devletleri’nde ve Batı Avrupa'da Birinci Dünya Savaşı sonrasında öneminin arttığı görülmektedir.

Batı'da ki siyasal pazarlama uygulamalarının aksine, Türkiye'de gerçekleştirilen uygulamalar propaganda hedefli olup yalnızca seçim dönemlerinde yapılmaktadır. Marka esaslı araştırmalar ise, son dönemde karşımıza çıkan uygulamalardandır. Önceleri, seçmenin karar verme sürecinde ideolojik unsurlar ve iletişim becerileri etkili olurken günümüzde farklı etmenler önem kazanmaya başlamıştır. $\mathrm{Bu}$ doğrultuda, parti ve liderlerin marka stratejileri noktasında etkin bir marka değeri oluşturması önemini arttırmaya başlamıştır. Dolayısıyla seçmenin karar verme sürecinde parti ve liderlerle ilgili oluşturulacak marka algısı etkili olmaktadır.

Siyasal markaların esas hedefi, seçmenin karar verme sürecini etkisi altına alarak ideolojilerinin daha kolay benimsenmesini sağlamaktır. Siyaset kavramı içinde yer alan ögeleri marka olarak düşünmek ve stratejileri bu doğrultuda geliştirmek için öncelikle marka kişiliği ve uygulamalarını yapılan planlamalara entegre etmek elzemdir. Ticari ürünlere benzer şekilde siyasal alandaki ürünler de programlı ve bilinçli bir şekilde tasarlanmış bir marka kişiliği algısına sahip olduklarında marka yönetimini daha aktif gerçekleştirmektedirler.

Bu çalışmanın amacı, 31 Mart 2019 yerel seçimleri doğrultusunda, TBMM'de \%10 barajını aşan siyasal partilerin Uşak’ta ki belediye başkan adaylarının seçmen gözünde marka kişiliklerinin incelenmektir. Çalışmada öncelikle siyasal pazarlama ve marka kişiliği konusundaki teoriye yer verilmiş ve daha sonrasında bu teoriyi destekleyen araştırmanın yöntem ve bulgularımdan bahsedilmiştir.

\section{Siyaset ve Pazarlama İlişkisi}

Siyasal pazarlama kişilerin ve fikirlerin pazarlanması olarak düşünüldüğünde fikirlerin pazarlanması kavramı, siyasi partilerin ülkenin yaşadığ 1 problemleri belirlemeleri, bunlara neden olan faktörleri tespit etmeleri ve çözüm odaklı önerilerini seçmene kabul ettirme faaliyetlerini kapsar. Bu bağlamda seçmen ile kurulmak istenilen iletişimin amacı, seçmenin oyunu siyasal pazarlama uygulamalarıyla kazanmaktır (Tan, 2002: 22). Tek (1999: 25) siyasal pazarlamay1, bireyin siyasi partilerden aday gösterilmesi, seçilmesi ya da partilerin yönetime gelmesi amacıyla planlanan pazarlama faaliyetleri olarak tanımlamaktadır. Siyasette en büyük amaç, parti, aday veya liderlerin programlarını, görüşlerini bir ürün olarak şekillendirilip seçmenin tercih etmesini sağlamaktır. Bu amacı gerçekleştirmenin yolu ise, hedef 
kitlelere yönelik iletişim araçları kullanmaktır. Siyasi partilerin gerçekleştirdiği etkinlikler, siyasal yaşamdaki pazarlama çabalarıdır (Bayraktaroğlu, 2002: 62).

Siyasal pazarlamada partiler gayelerine ulaşabilmek, diğer partilerden önde olabilmek, mevcudiyetlerini sürdürebilmek ve seçmenlerin hafızalarında sürekli yer alabilmek için güçlü bir tanıtıma ihtiyaç duyarlar. $\mathrm{Bu}$ nedenle siyasal pazarlama sadece seçim dönemlerini kapsamamakla beraber partiler var oldukça ihtiyaç duyulan çalışmalar bütünü olarak ele alınmalıdır (Kurtuldu ve Kırkbir, 2005: 59). Keresteci (2006: 94) için ise siyasal pazarlama, adayın her bir seçmeninin kendisini tanıması, hedef kitlesine uygun olması, rakiplerine ve muhalefete karşı farkını göstermesi amacıyla kullanılan tekniklerin bütünüdür. Siyasal pazarlama, aday ve partilerin gereksinimlerinin belirlenmesiyle oluşur. Bu gereksinimlerin karşılanmasına yönelik çözümler üretilip farklı stratejilerle seçmenlere ulaştırılırken karşılık olarak seçmenlerin oyunu kazanmaya gayret edilir. Ardından, adaylar ve partiler, oy verenlerin memnuniyetini ve sürekli desteğini kazanabilmek adına siyasal iletişimi zorunlu hale getirirler (Aydoğan, 2007: 57).

Siyasal pazarlama, ticari pazarlama tekniklerini kullandığı için birbirlerine oldukça benzemektedirler. $\mathrm{Bu}$ anlamda siyasal pazarlama; seçmen ihtiyaçlarının tespitinden başlayarak, bunların giderilmesine yönelik ideal olan siyasal ürünlerin geliştirilmesi, fiyatının makul olması, etkin bir şekilde dağıtımı ve tutundurulmasını içeren süreçlerden oluşmaktadır (Külter ve Polat, 2008: 107). Özgüven ve Demirtaş (2012: 88) için siyasal pazarlama, partilerin ürün karmalarını yani lider, parti programı vs. seçmenlerce istenebilir hale getirmek amacıyla yapılan bütün faaliyetleri kapsamaktadır.

Özkan (2014: 58), toplumun ihtiyaç ve taleplerini karşılamaya yönelik, aday ve partilerin, programlarının seçmene tanıtılması ve tutundurulması kapsamındaki tüm eylemleri siyasal pazarlama olarak tanımlamaktadır. $\mathrm{Bu}$ süreçte fikirler pazarlanmakta olduğu için siyasal reklamdan üye tutumuna kadar tüm etkinliklerin olabildiğince aynı dili konuşması önemli bir ayrıntıdır. Parti üyeleri, üye olmayı düşünenler, yandaşlar ve hatta oy vermeyenler hedef seçmeni oluşturmaktadır. Siyasal pazarlama temelde ticari pazarlama gibi hareket etmektedir. İşletmeler pazarlama süreçlerini yönetirken öncelikle ortaya ir ürün koymakta daha sonra fiyatını belirlemektedir. Ürünün tüketiciye daha cazip ve makul gelmesi için de çeşitli tutundurma çabalarına yer verilmektedir. Birtakım farklı ürünler ve reklamlarla dikkat çekmek amaçlanmaktadır. Sonraki aşamada belirlenen noktalara açtıkları şubelerle, bayiler veya alışverişs merkezleri ile tüketiciye ulaşmaktadırlar. (Kelly ve Ashaiagbor, 2011:26).

Pazarlama bireysel ve sosyal gereksinimlerin karşılanmasıdır. $\mathrm{Bu}$ tanımdan da anlaşılacağı üzere pazarlama ve siyaset arasında yakın bir ilişki bulunmaktadır. Zira demokratik toplumlarda yurttaşlar oy vermek suretiyle seçimlere dâhil olmaktadırlar. Dolayısıyla bu durum toplumun sosyal bir ihtiyacıdır (Kotler, 2000: 430). Ticari pazarlamada amaç, ürün ve hizmetlerin toplumun satın alma hissiyatını arttırmaya yönelik bir kavram iken; siyasette oylama yoluyla siyasal tercihlerini belirleyen seçmenlere yönelik oy tercihlerini yönlendirme çabasıdır. Tüketicinin ticari pazarlamada adı 'müşteri' siyasal pazarlamada ise 'seçmen'dir. Ancak tamamen farklı anlaşılan iki kelimenin anlamı pazarlama disiplininde aynıdır (Tek, 1999: 68).

Seçmen oy tercihlerini belirlerken gelenek, kültür, aile, arkadaş tavsiyeleri gibi etmenlerin çoğu zaman etkisinde kalmaktadır. Bunların yanı sıra, siyasi adayın geçmişine duruşuna, tutumuna, politikasına, imajına da itibar gösterir. Bu niteliklerin tamamı bir siyasetçi için ürün kavramı oluşturmaktadır. Seçmenin adaylardan veya siyasi partilerden birini diğerine tercih eden 'müşteri' olduğu unutulmamalıdır (Qualter, 1991: 137). Adayı ya da siyasi partiyi ürün olarak benimseyen seçmeni etkilemek ve yakın tutmak için siyasal kampanyalara ihtiyaç duyulmaktadır. Bu aşamada pazarlama kavramı, siyasetçilere ve partilere kampanya düzenleme noktasında yardımcı olmaktadır. Ancak etkili ve verimli bir pazarlama anlayışı için gerçekçi ve fayda sağlayan bir zemin hazırlanmalı; aşırılık içeren, yerine getirilemeyecek vaatlerden ve seçmeni kampanyadan uzaklaştıracak söylemlerden geri durulmalıdır (Mauser, 1983: 23).

Adayların ve siyasi partilerin aslında birer oyuncu oldukları ve bu oyunda en iyi oynayanın kitleleri kazandığı unutulmamalıdır (Maarek, 1995: 55-57). Bu durum ABD’de yıllardır varlığını sürdürmekte ve Avrupa'da etkisine girmiş bulunmaktadır. Zira seçmenler oy verdikleri siyasi partilere bağlıdırlar fakat 
özellikle kendilerine yakın hissettikleri siyasilere oy verme eğiliminde olurlar (De Landtsheer, De Vries ve Vertessen, 2008: 222).

Pazarlama ve siyaset kavramlarında benzer noktalar bulunmaktadır. Zira her iki alanda da pazarlama araştırması yapmak, akabinde bölümlendirmek, hedef pazarı belirlenmek ve bütün araştırmaların ışığında güçlü bir strateji geliştirmek gerekmektedir (Gürbüz ve İnal, 2004: 52).

\section{Siyasal Marka Kişiliği}

Marka kişiliği kavramından ilk kez 1955'de söz eden Gardner ve Levy olmuştur. Ardından 1970'li yıllarda Kapferer marka kişiliği alanında çeşitli çalışmalar yapmıştır. Kapferer'in (1970) yapmış olduğu marka kişiliği tanımında, markanın dışarıya dönük olan yüzü ile marka ile ilişkilendirilen karakter özelliklerinin birleşimi olduğunu savunmaktadır. Markham (1972), işletmenin de kişilik kavramı ölçeğini kullanması gerektiğini ilk öne sürmekte ve marka kişiliğinin, ürünün değerlendirilmesinde önemli araçlardan biri olduğunu belirtmektedir. 1970'li yıllarda ortaya çıkan marka kişiliği pazarlama yönetimi için önemli bir araştırma alanıdır. Markanın da bir kişiliğe sahip olduğu ve satın alan tüketicinin kendi kişiliğine uygun olanı tercih etmesi pazarlama alında çekiciliğini her geçen gün arttırmaktadır (Yüksel, 2010: 26).

Gardner ve Levy (1955) marka kişiliği kavramını genel imaj ve karakter yapısı olarak tanımlamakta ve markanın genel satış durumuna ilave olarak ürünün teknik özelliğinin ve sağladığı faydaların önemli ve kalıcı olduğunu belirtmektedirler. Aaker (1997) tarafından tanımlanan ve genel kabul gören marka kişiliği , marka ile anılan ve insana ait tüm özellikleri içeren bir bütündür (Aaker, 1997: 347). Bu özellikler tüketicinin marka ile doğrudan ve dolaylı olarak ilişkilendirilmesi ile oluşmaktadır. Örneğin, markanın somut bir varlık olmadığı, hareket kabiliyeti olmadığ1, düşünemeyeceği ve hissedemeyeceği fakat tüketicinin zihnindeki algılamaların tamamını yaratarak marka kavramının soyut ancak önemli özelliklere sahiptir. Marka kişiliği, tüketici için sosyal kimlik anlamına gelebilmekte ve tüketicinin olmasını istediği ideal ve sosyal benliğinin ifadesinin de işleyişini sağlamaktadır (Wang ve Yang, 2008: 459).

Pazarlama kapsamında ürün ile ilgili belirleyici ölçütler soyut ve somut bileşenlerden oluşmaktadır. Somut bileşenler çoğunlukla ürünün, fiziksel, fonksiyonel tarafinı anlatırken; soyut bileşenler ise daha çok marka, firma ilişkisini, biçimini, algılanan kaliteden oluşmaktadır. Rakip markalar arasında gidip gelen tüketici, satın alma kararını verirken değerlendirme sürecinde elde ettiği bilgiler genellikle pazarlama iletişiminden kaynaklanmaktadır. Bu açıdan tüketicinin rakip ürünler arasında yaptığı tercihleri belirleyen pazarlama iletişimi deneyimleri çeşitliliğin oluşmasında yardımcı olmaktadır (Uztuğ, 1999: 136). Günümüz pazarlamada fikirler, kişiler, kurumlar gibi tüm somut ve soyut varlıkları kapsayan ürün; siyasal pazarlamada ise siyasal ideolojinin, kişilerin ve örgütlerin de pazarlamasını içeren karmaşık bir yapı halini almaktadır. Bu karmaşık ürünün de diğer ticari ürünler gibi farklılaşmaya, genişlemeye ve tüketici algısında olumlu anlamda rakiplerinden farklı bir yere konumlandırılma ihtiyacı duymaktadır. Bu ise ancak "siyasal marka" ile mümkün almaktadır (Boyraz, 2015: 350).

French ve Smith (2010) siyasal markayı; seçmenin aklında tuttuğu ve anımsatıldığında ulaşılabilir olan, birbiriyle ilişkili siyasal bilginin çağrışımına olanak veren kavram olarak tanımlamaktadırlar (aktaran Toksarı ve Dağc1, 2013: 1357). Siyasal marka, seçmene siyasal partiyi veya adayı, lideri, partinin programını tanıtan, bunları diğer siyasal partilerden ayırmayı sağlayan isim, logo, sembol, şekil ve bunların toplamı şeklinde tanımlanabilmektedir (Yüce, 2014: 46). Siyasal marka, siyasal hayatta rakiplerinden farklı nitelikleriyle ayrılan, iz bırakan, seçmenin oy tercihini kazandığı kişi veya kurumlardır.

Siyasi partilerin liderleri, siyasal markayı oluşturmakta ve semboller, terimler de oluşturulan bu markayı sağlamlaştırmak ve güçlendirmek için kullanılmaktadırlar. Siyasal markalamada: parti, lider, aday, parti örgütleri vb. gibi çeşitli siyasal ürünler ortak bir markayı oluşturmada öne çıkmaktadırlar. Tüm bu ürünlerin siyasal markayı nasıl yüklendiği, hangi şekilde simgelediği gibi konular tam anlamıyla denetlenemediğinden marka imajında belirsizlikler ve tutarsızlıklar meydana gelebilmektedir 
(Bayraktaroğlu, 2002: 70). Siyasal markalama, siyasal marka imajının yaratılmasında, tüketici markalaşma yöntemlerinin planlı olarak kullanımıdır. Özellikle, siyasetçilerin herkes tarafından beğenisini kazanmak ve seçimleri kazanarak yönetime gelmek için başvurdukları taktikler anlamına gelmektedir. Siyasal markalama, sadece reklam taktiklerinden ziyade, her şeyi sınırları içine alan bir pazarlama ve imaj-kimlik programıdır (Karayel Bilbil ve Çelikkol, 2015: 239).

Siyasette seçim kampanyaları, pazarlama, iletişim faaliyetleri sonrasında 1990'ların sonuna doğru markalaşma aşamasına ulaşılmıştır (Uztuğ, 2011: 66). Siyasi partilerin, seçim süreçlerinde "siyasal marka" olarak rakiplerinden ayrılması ve "farkındalık" yaratması oldukça önemlidir. Markanın "görsel ve algısal özellikleri olan", "paha biçilen", "imaj oluşturan”, "kişilik katan”, "konumlandıran” bir faktör olduğunu ya da "farklılaştırma", "eşsiz kılma", "ürünü hatırlatma", "satın alma tercihine etki etme", "çağrışım yaratma", "kimlik yaratma", gibi işlevleri yerine getirdiği anlaşılmaktadır (Küçükerdoğan, 2011: 68). Siyasal alandaki markalaşma sürecinde, var olan siyasi ürünler arasında doğru ve net ayrımların azalması durumu gerçekleşmektedir. Sonuç olarak marka, rakiplerden farklı olmanın, seçmenin bağ lılığını kazanmada önemli araçlardan biridir. Siyasal anlamda markalaşma, siyasi partilerin kurumsal marka olması ve siyasetçilerin ya da siyasi adayların kişisel marka olması şeklinde olmaktadır (Uztuğ, 2009: 63).

Tüketici nezdinde bir siyasi partinin marka kişiliği; seçmen zihninde bu marka ile ilgili şekillenen, bellekte tutulan ve marka ismi anıldığında çağrışımlara neden olan insani kişilik özellikleridir (Smith, 2009: 212). Seçmenin siyasi parti için düşündüğü bu kişilik özellikleri ve bunların da bireyin özellikleri ile uyumu seçmenin siyasal partiye olan yakınlığının öznesi olacaktır. Tıpkı geleneksel pazarlamada olduğu gibi seçmen de kendine ve kişiliğine yakın hissettiği siyasi partiye oy verecek, verdiği siyasal satın alma kararını kendinin bir ifadesi olarak görecektir. Bu yakınlık hissi belki de geleneksel pazarlamadan daha önemlidir. Çünkü siyaset pazarlaması bakımında seçmen kararının maliyeti tüketicinin maliyetine oranla yüksektir. Yanlış kararın maliyeti çoğu zaman bireysel değil toplumsaldır ve karardan dönüş için en yakın süre bir sonraki seçim sürecidir. $\mathrm{Bu}$ nedenle seçmenin siyasi partiye duyduğu yakınlık ve ona atfettiği olumlu kişilik özellikleri, tekrarlayan siyasal satın almalar için oldukça önemlidir. Siyasal markalaşma bir politik imajın inşasında ticari pazarlamadaki markalaşma taktiklerinin stratejik olarak kullanımıdır ve siyasal marka; siyasi partinin kendisi, lideri, adaylarının bir bileşimini ifade etmektedir (Bilbil Karayel ve Çelikkol, 2015: 239).

Marka kişiliği siyasal kapsamda, Phipps ve arkadaşları tarafından gerçekleştirilen çalışmada seçmen algısında oluşan marka bağlılığının tüketici doyumuna tabi olduğunu, siyasi partilerin tatmininin ise seçmenin sadık olmasına bağlı olduğunu, kalitenin liderlik olarak kabul görüldüğünü ve seçmen algısında önemli bir yeri olduğunu aktarmışlardır. Değer, marka kişiliği ve organizasyon kavramını markanın çağrışım boyutu olarak kabul edildiğinin ve tanınmamış bir siyasetçinin güçlü bir marka kişilik değerine sahip olmasının oldukça zor olduğunu belirtmişlerdir (Phipps vd., 2010: 494-514).

\section{Yöntem}

Siyasi partilerin genelde ve yerelde temel hedefi seçimleri kazanıp iktidar olmaktır. Dolayısıyla bu hedefi gerçekleştirebilmek için geniş kitlelere ulaşmak kaçınılmaz bir zorunluluktur. Bu zorunluluk pazarlama faaliyetlerinin siyasete uyarlanması gerekliliğini de beraberinde getirmiştir. $\mathrm{Bu}$ bağlamda pazarlama araçlarından biri olan marka kişiliği son zamanlarda kullanılmaya başlamıştır. Buradan hareketle, belediye başkan adaylarının seçmen gözündeki marka kişilik boyutlarını belirlemek amacıyla bu çalışma gerçekleştirilmiştir. Bu amaç doğrultusunda 31 Mart 2019 yerel seçimlerinde Uşak İl Belediye Başkan adaylarının marka kişilik boyutlarını tespit için 2018 genel seçim sonuçlarına göre \%10'luk seçim barajını aşan AKPARTİ, CHP, MHP ve İYİ PARTİ adayları araştırma kapsamına alınmış diğer parti ve bağımsız adaylar ise araştırma kapsamı dışında tutulmuştur. Araştırmada kullanılan veriler 01-30 Mart 2019 tarihleri arasındaki anket yöntemi elde edilmiştir. Çalışmanın ana kütlesini, Uşak ili merkez ilçede yaşayan 18 yaş ve üzeri oy kullanma hakkı olan oluşturmaktadır. Uşak şehir merkezinin 2020 yılı nüfus sayımına göre nüfusu 370.509 kişidir. \% 95 güven aralığında e=\%4 hata payı ile örneklem büyüklüğü n=387 olarak belirlenmiştir. Toplam 607 kişi ile görüşülmüş oy vereceği adayı belirlemeyen kararsız 387 
seçmene anket uygulanmıştır. Eksik ve hatalı doldurulan anketlerin elenmesi sonucu 316 anket değerlendirmeye alınmıştır.

Araştırmada üç grup değişken yer almaktadır. İlk bölümde, 42 ifadeden oluşan marka kişilik ölçeğin hazırlanmasında Decker (2015)'in çalışmasından yararlanılmıştır. İkinci grup sorular seçmenlerin siyasi düşüncelerini oluşturan sorulardan oluşmuş ve son grupta ise ekonomik ve demografik sorular yer almıştır. Verilerin analizinde SPSS 23 ve AMOS 23 istatistik programları kullanılmıştır. Araştırmada ortalamalar, standart sapma, frekans dağılımları, güvenilirlik ve doğrulayıcı faktör analizleri yapılmıştır.

\section{Bulgular}

Araştırma kapsamına alına seçmenlerin ekonomik ve demografik özellikleri şu şekildedir;

\%56.6's1 erkek ve \%43.4'ü kadındır, \%9.2'si 18-24, \%26.6's1 25-31, \% 27.5'i 32-38, \%18'i 39-45, \%12.7'si 46-52, \%3.5'i 53-59, \%2.5'i 60 ve üzeri yaş grubunda yer almaktadır. Seçmenlerin \%61.4'ü evli ve \%38.6'sı bekârdır. Sahip olunan aylık gelir miktarı açısından \%35.8'i 0-2000, \%34.2'si 2001-4000, \%25'i 4001-6000, \%2.8'i 6001-8000, \%1.6's1 8001-10000 ve \%0.6's1 10000 ve üzeri gelire sahiptirler. Cevaplayıcıların \%15.5'i ilköğretim, \%43.4'ü lise, \%38.3'ü üniversite, \%2.8'i lisans üstü eğitim düzeyine sahiptir. Meslek gruplarına göre ise; \%11.1'i ev hanımı, \%25.9'u memur, \%35.4'ü işçi, \%13.3'ü serbest meslek, \%2.8'i emekli, \%6.3'ü esnaf, \%1.6'sı çiftçi, \%3.5'i öğrenciler oluşturmaktadır.

Araştırmaya kapsamında yer alan seçmenlerin \%67.4'ü seçim için açıklanan projeleri bilirken, \%32.6's1 bilmediğini ifade etmiştir. \%69.3'ü adayları takip ettiğini, \%30.7'si ise etmediğini, \%90.5'i oy kullanacağını, \%9.5'i ise kullanmayacağını belirtmiştir. 24 Haziran 2018 genel seçimlerinde katılımcılar \%26.0 ile AKPARTİ'ye, \%27.5 ile CHP'ye, \%15.2 ile MHP'ye, \%19.6 ile İYİ Parti'ye, \%11.7'si ise diğer partilere oy verdiklerini ifade etmişlerdir. Siyasi görüş açısından seçmenlerin \%3.5'i liberalist, \%0.9 kapitalist, \%22.5'i muhafazakar, \%18.4'ü demokrat, \%33.2'si cumhuriyetçi, \%15.2'si milliyetçi ve diğer siyasi düşüncelere mensup bireylerin oranları \%6.3 olarak tespit edilmiştir.

Decker (2015) tarafindan geliştirilen siyasi marka kişilik ölçeği; kendini beğenmiş, yetersiz, yetenekli, heyecan verici, samimi ve kuvvetli boyutlarından oluşmaktadır. Cevaplayıcıların siyasi adayların marka kişiliği ile ilgili yargılara katılma dereceleri 5'li likert ölçeği (5=Tamamen katılıyorum, 1=Kesinlikle katılmıyorum) ile ölçülmüştür. Bu boyutlara ait kişilik özelliklerinin araştırmada yer alan adaylara ait aritmetik ortalama, standart sapma ve alfa güvenilirlik katsayıları aşağıdaki tabloda sunulmuştur.

Tablo 1. Belediye Başkan Adaylarının Marka Kişilik Özelliklerine Yönelik Alg1 ve Tutumlar

\begin{tabular}{|l|c|c|c|c|c|c|c|c|}
\hline \multirow{2}{*}{} & \multicolumn{2}{|c|}{ A Adayı } & \multicolumn{2}{c|}{ B Adayı } & \multicolumn{2}{c|}{ C Adayı } & \multicolumn{2}{c|}{ D Adayı } \\
\cline { 2 - 11 } & Art.Ort. & St.Sap. & Art.Ort. & St.Sap. & Art. Ort. & St.Sap. & Art. Ort. & St.Sap. \\
\hline \multirow{2}{*}{ Kendini beğenmiş } & \multicolumn{2}{|c|}{$\boldsymbol{\alpha}=\mathbf{0 . 8 6 3}$} & \multicolumn{2}{|c|}{$\boldsymbol{\alpha}=\mathbf{0 . 8 1 9}$} & \multicolumn{2}{c|}{$\boldsymbol{\alpha}=\mathbf{0 . 8 1 6}$} & \multicolumn{2}{c|}{$\boldsymbol{\alpha}=\mathbf{0 . 8 2 2}$} \\
\hline Sahtekâr & 2.70 & 1.54 & 2.61 & 1.46 & 2.44 & 1.43 & 2.46 & 1.43 \\
\hline Hilekâr & 2.61 & 1.54 & 2.87 & 1.50 & 2.50 & 1.42 & 2.62 & 1.51 \\
\hline Görkemli & $* 2.37$ & $* 1.42$ & $* 2.28$ & $* 1.33$ & $* 2.25$ & $* 1.34$ & $* 2.54$ & $* 1.42$ \\
\hline Gösteriş meraklısı & 2.64 & 1.48 & 2.99 & 1.46 & 2.57 & 1.44 & 2.67 & 1.44 \\
\hline Vurdumduymaz & 2.43 & 1.50 & 2.49 & 1.41 & 2.41 & 1.41 & 2.38 & 1.42 \\
\hline İlgisiz & 2.29 & 1.51 & 2.40 & 1.45 & 2.34 & 1.40 & 2.07 & 1.31 \\
\hline Kibirli & 2.34 & 1.48 & 2.58 & 1.46 & 2.19 & 1.32 & 2.21 & 1.36 \\
\hline İnatçı & $* 2.99$ & $* 1.41$ & $* 3.21$ & $* 1.43$ & $* 2.73$ & $* 1.31$ & $* 3.29$ & $* 1.40$ \\
\hline Kuruntulu & 2.48 & 1.46 & 2.66 & 1.53 & 2.40 & 1.40 & 2.54 & 1.52 \\
\hline Burnu havada & 2.70 & 1.54 & $* 3.25$ & $* 1.44$ & 2.54 & 1.36 & $* 2.62$ & $* 1.52$ \\
\hline
\end{tabular}




\begin{tabular}{|c|c|c|c|c|c|c|c|c|}
\hline \multirow{2}{*}{$\begin{array}{l}\text { Yapmacık } \\
\text { Yetersiz }\end{array}$} & 2.90 & 1.56 & 2.93 & 1.49 & 2.72 & 1.50 & 2.75 & 1.52 \\
\hline & \multicolumn{2}{|c|}{$\alpha=0.750$} & \multicolumn{2}{|c|}{$\alpha=0.734$} & \multicolumn{2}{|c|}{$\alpha=0.693$} & \multicolumn{2}{|c|}{$\alpha=0.730$} \\
\hline Aciz & 2.22 & 1.46 & 2.28 & 1.42 & 2.11 & 1.34 & $* 2.18$ & $* 1.39$ \\
\hline Sorumsuz & 2.49 & 1.51 & 2.73 & 1.46 & 2.54 & 1.41 & 2.30 & 1.38 \\
\hline Etkisiz & 2.53 & 1.56 & 2.57 & 1.55 & 2.54 & 1.48 & 2.55 & 1.50 \\
\hline Beceriksiz & 2.66 & 1.52 & 2.77 & 1.53 & 2.57 & 1.45 & 2.39 & 1.45 \\
\hline Dikkatsiz & 2.75 & 1.46 & $* 2.85$ & $* 1.41$ & 2.69 & 1.34 & $* 2.58$ & $* 1.37$ \\
\hline Yetenekli & \multicolumn{2}{|c|}{$\alpha=0.774$} & \multicolumn{2}{|c|}{$\alpha=\mathbf{0 . 7 5 3}$} & \multicolumn{2}{|c|}{$\alpha=0.736$} & \multicolumn{2}{|c|}{$\alpha=0.765$} \\
\hline İşbirlikçi & 2.61 & 1.45 & $* 2.45$ & $* 1.40$ & 2.47 & 1.33 & $* 2.64$ & $* 1.43$ \\
\hline Sağlam karakterli & 2.77 & 1.39 & 2.57 & 1.37 & 2.75 & 1.39 & 2.96 & 1.40 \\
\hline Bilgili & 2.72 & 1.35 & 2.78 & 1.37 & 2.52 & 1.32 & 2.99 & 1.37 \\
\hline Lider & 2.60 & 1.37 & 2.51 & 1.34 & 2.49 & 1.34 & 3.11 & 1.42 \\
\hline Anlayışlı & 2.75 & 1.35 & 2.63 & 1.33 & 2.80 & 1.31 & 3.14 & 1.42 \\
\hline Heyecan verici & \multicolumn{2}{|c|}{$\alpha=0.817$} & \multicolumn{2}{|c|}{$\alpha=0.797$} & \multicolumn{2}{|c|}{$\alpha=0.809$} & \multicolumn{2}{|c|}{$\alpha=0.788$} \\
\hline Sikıcı & $* 3.12$ & $* 1.55$ & $* 3.10$ & $* 1.47$ & $* 3.20$ & $* 1.48$ & $* 2.97$ & $* 1.51$ \\
\hline Azimli & 2.93 & 1.41 & 3.06 & 1.49 & 2.81 & 1.36 & 3.32 & 1.49 \\
\hline Enerjik & 3.20 & 1.39 & 2.97 & 1.43 & 2.82 & 1.37 & 3.32 & 1.41 \\
\hline Heyecanlı & 3.37 & 1.50 & 3.14 & 1.52 & $* 3.13$ & $* 1.49$ & 3.18 & 1.52 \\
\hline Hayalperest & $* 2.71$ & $* 1.47$ & $* 2.80$ & $* 1.44$ & $* 2.82$ & $* 1.39$ & $* 2.80$ & $* 1.51$ \\
\hline Modern & 2.89 & 1.44 & 2.95 & 1.44 & 2.92 & 1.42 & 3.30 & 1.38 \\
\hline Özgür & 2.47 & 1.57 & $* 2.43$ & $* 1.52$ & 2.41 & 1.47 & $* 2.54$ & $* 1.54$ \\
\hline Özgün & 2.64 & 1.39 & 2.77 & 1.33 & 2.58 & 1.38 & 3.12 & 1.43 \\
\hline Çağdaş & 2.76 & 1.36 & 2.91 & 1.32 & 2.65 & 1.30 & 3.12 & 1.37 \\
\hline Mükemmel & 2.20 & 1.41 & $* 2.15$ & $* 1.37$ & 2.18 & 1.40 & $* 2.37$ & $* 1.45$ \\
\hline Samimi & \multicolumn{2}{|c|}{$\alpha=0.820$} & \multicolumn{2}{|c|}{$\alpha=0.768$} & \multicolumn{2}{|c|}{$\alpha=0.746$} & \multicolumn{2}{|c|}{$\alpha=0.810$} \\
\hline Neşeli & 3.18 & 1.50 & 2.97 & 1.42 & 2.88 & 1.39 & 3.29 & 1.48 \\
\hline Cana yakın & 3.02 & 1.51 & 2.52 & 1.34 & 2.73 & 1.34 & 3.15 & 1.45 \\
\hline Mutlu & 3.51 & 1.46 & 3.22 & 1.47 & 3.29 & 1.39 & 3.61 & 1.43 \\
\hline Candan & 2.87 & 1.37 & 2.52 & 1.27 & 2.76 & 1.35 & 3.06 & 1.34 \\
\hline Gerçekçi & 2.61 & 1.45 & 2.46 & 1.33 & 2.49 & 1.36 & 2.97 & 1.40 \\
\hline Erdemli & 3.02 & 1.43 & 2.82 & 1.41 & 2.86 & 1.39 & $* 3.15$ & $* 1.43$ \\
\hline Kuvvetli & \multicolumn{2}{|c|}{$\alpha=0.761$} & \multicolumn{2}{|c|}{$\alpha=0.609$} & \multicolumn{2}{|c|}{$\alpha=0.672$} & \multicolumn{2}{|c|}{$\alpha=0.524$} \\
\hline Gözü pek & 2.61 & 1.44 & 2.75 & 1.42 & 2.66 & 1.39 & 2.98 & 1.46 \\
\hline Dürüst & 2.73 & 1.47 & 2.39 & 1.43 & 2.69 & 1.40 & 2.89 & 1.50 \\
\hline Erkeksi & 3.12 & 1.56 & 3.17 & 1.56 & $* 3.31$ & $* 1.57$ & 3.31 & 1.57 \\
\hline Korkusuz & 2.36 & 1.42 & $* 2.43$ & $* 1.38$ & $* 2.43$ & $* 1.46$ & 2.62 & 1.47 \\
\hline Sağlam/kat1 & 2.35 & 1.50 & $* 2.61$ & $* 1.41$ & $* 2.15$ & $* 1.33$ & $* 2.23$ & $* 1.38$ \\
\hline
\end{tabular}

“Kendini Beğenmiş” boyutunda yer alan özelliklere adaylar için verilmiş olan yanıtlara göre; A adayının en yüksek özelliği, 2.90 ortalama ile yapmacık, 2.70 ortalama ile burnu havada ve 2.70 ortalama ile sahtekâr olarak tespit edilmiştir. Ayrıca boyutun Cronbach Alfa Güvenilirlik katsayı oranının 0.863 ile çok iyi seviyede olduğu görülmektedir. B adayının en yüksek özelliği, 2.99 ortalama ile gösteriş meraklısı, 2.93 ortalama ile yapmacık ve 2.87 ortalama ile hilekâr olduğu gözlemlenmiştir. Boyutun Cronbach Alfa Güvenilirlik katsayı oranının 0.819 ile çok iyi seviyede olduğu görülmektedir. C adayının en yüksek özelliği, 2.72 ortalama ile yapmacık, 2.57 ortalama ile gösteriş meraklısı, 2.54 ortalama ile burnu havada olarak değerlendirilmiştir. Boyutun Cronbach Alfa Güvenilirlik katsayı oranının 0.816 ile çok iyi seviyede olduğu gözlemlenmiştir. D adayının en yüksek ortalamaya sahip özelliği ise, 2.75 ile yapmacık, 2.67 ile gösteriş meraklısı ve 2.62 ile hilekâr olduğu tespit edilmiştir. Cronbach Alfa Güvenilirlik katsayı oranı 0.822 ile çok iyi seviyededir.

Cevaplayıcıların, "Yetersiz" boyutunda yer alan marka kişilik özelliğine sahip adaylar için vermiş olduğu yanıtlara göre; A adayının en yüksek özelliği, 2.75 ortalama ile dikkatsiz, 2.66 ortalama ile beceriksiz ve 
2.53 ortalama ile etkisiz olarak tespit edilmiştir. Ayrıca boyutun Cronbach Alfa Güvenilirlik katsayı oranının 0.750 ile iyi seviyede olduğu görülmektedir. B adayının en yüksek özelliği, 2.77 ortalama ile beceriksiz, 2.73 ortalama ile sorumsuz ve 2.57 ortalama ile etkisiz olduğu gözlemlenmiştir. Boyutun Cronbach Alfa Güvenilirlik katsayı oranının 0.734 ile iyi seviyede olduğu görülmektedir. C adayının en yüksek özelliği, 2.69 ortalama ile dikkatsiz, 2.57 ortalama ile beceriksiz, 2.54 ortalama ile sorumsuz olarak değerlendirilmiştir. Boyutun Cronbach Alfa Güvenilirlik katsayı oranının 0.693 ile orta seviyede olduğu gözlemlenmiştir. D adayının en yüksek ortalamaya sahip özelliği ise, 2.55 ile etkisiz, 2.39 ile beceriksiz ve 2.30 ile sorumsuz olduğu tespit edilmiştir. Cronbach Alfa Güvenilirlik katsayı oranı 0.730 ile iyi seviyededir.

Cevaplayıcıların, "Yetenekli" boyutunda A adayının en yüksek özelliği, 2.77 ortalama ile sağlam karakterli, 2.75 ortalama ile anlayışlı ve 2.72 ortalama ile bilgili olarak tespit edilmiştir. Ayrıca boyutun Cronbach Alfa Güvenilirlik katsayı oranının 0.774 ile iyi seviyede olduğu görülmektedir. B adayının en yüksek özelliği, 2.78 ortalama ile bilgili, 2.63 ortalama ile anlayışlı ve 2.57 ortalama ile sağlam karakterli olduğu gözlemlenmiştir. Boyutun Cronbach Alfa Güvenilirlik katsayı oranının 0.753 ile iyi seviyede olduğu görülmektedir. C adayının en yüksek özelliği, 2.80 ortalama ile anlayışlı, 2.75 ortalama ile sağlam karakterli, 2.52 ortalama ile bilgili olarak değerlendirilmiştir. Boyutun Cronbach Alfa Güvenilirlik katsay1 oranının 0.736 ile iyi seviyede olduğu gözlemlenmiştir. D adayının en yüksek ortalamaya sahip değişkenleri ise, 3.14 ile anlayışılı, 3.11 ile lider ve 2.99 ile bilgili olduğu tespit edilmiştir. Cronbach Alfa Güvenilirlik katsayı oranı 0.765 ile iyi seviyededir.

Cevaplayıcıların, "Heyecan Verici” boyutunda A adayının en yüksek özellik, 3.37 ortalama ile heyecanlı, 3.20 ortalama ile enerjik ve 2.93 ortalama ile azimli olarak tespit edilmiştir. Ayrıca boyutun Cronbach Alfa Güvenilirlik katsayı oranının 0.817 ile çok iyi seviyede olduğu görülmektedir. B adayının en yüksek özelliği, 3.14 ortalama ile heyecanlı, 3.06 ortalama ile azimli ve 2.97 ortalama ile enerjik olduğu gözlemlenmiştir. Boyutun Cronbach Alfa Güvenilirlik katsayı oranının 0.797 ile iyi seviyede olduğu görülmektedir. C adayının en yüksek özelliği, 2.92 ortalama ile modern, 2.82 ortalama ile enerjik, 2.81 ortalama ile azimli olarak değerlendirilmiştir. Boyutun Cronbach Alfa Güvenilirlik katsayı oranının 0.809 ile çok iyi seviyede olduğu gözlemlenmiştir. D adayının en yüksek ortalamaya sahip özelliği ise, 3.32 ile azimli ve enerjik, 3.30 ile modern ve 3.18 ile heyecanlı olduğu tespit edilmiştir. Cronbach Alfa Güvenilirlik katsayı oranı 0.788 ile iyi seviyededir.

Cevaplayıcıların, "Samimi" boyutunda A adayının en yüksek özelliği, 3.51 ortalama ile mutlu, 3.18 ortalama ile neşeli ve 3.02 ortalama ile cana yakın ve erdemli olarak tespit edilmiştir. Ayrıca boyutun Cronbach Alfa Güvenilirlik katsayı oranının 0.820 ile çok iyi seviyede olduğu görülmektedir. B adayının en yüksek özelliği, 3.22 ortalama ile mutlu, 2.97 ortalama ile neşeli ve 2.82 ortalama ile erdemli olduğu gözlemlenmiştir. Boyutun Cronbach Alfa Güvenilirlik katsayı oranının 0.768 ile iyi seviyede olduğu görülmektedir. C adayının en yüksek özelliği, 3.29 ortalama ile mutlu, 2.88 ortalama ile neşeli, 2.86 ortalama ile erdemli olarak değerlendirilmiştir. Boyutun Cronbach Alfa Güvenilirlik katsayı oranının 0.746 ile iyi seviyede olduğu gözlemlenmiştir. D adayının en yüksek ortalamaya sahip özelliği ise, 3.61 ile mutlu, 3.29 ile neşeli ve 3.15 ile cana yakın olduğu tespit edilmiştir. Cronbach Alfa Güvenilirlik katsayı oranı 0.810 ile çok iyi seviyededir.

Cevaplayıcıların, "Kuvvetli" boyutunda A adayının en yüksek özelliği, 3.12 ortalama ile erkeksi, 2.73 ortalama ile dürüst ve 2.61 ortalama ile gözü pek olarak tespit edilmiştir. Ayrıca boyutun Cronbach Alfa Güvenilirlik katsayı oranının 0.761 ile iyi seviyede olduğu görülmektedir. B adayının en yüksek özelliği, 3.17 ortalama ile erkeksi, 2.75 ortalama ile gözü pek ve 2.39 ortalama ile dürüst olduğu gözlemlenmiştir. Boyutun Cronbach Alfa Güvenilirlik katsayı oranının 0.609 ile orta seviyede olduğu görülmektedir. C adayının en yüksek özelliği, 2.69 ortalama ile dürüst, 2.66 ortalama ile gözü pek olarak değerlendirilmiştir. Boyutun Cronbach Alfa Güvenilirlik katsayı oranının 0.672 ile orta seviyede olduğu gözlemlenmiştir. D adayının en yüksek ortalamaya sahip özelliği ise, 3.31 ile erkeksi, 2.98 ile gözü pek ve 2.89 ile dürüst olduğu tespit edilmiştir. Cronbach Alfa Güvenilirlik katsayı oranı 0.524 ile düşük seviyededir. 
Cevaplayıcılar ile araştırmada kullanılan marka kişilik ölçeğinin arasındaki uyumu görmek ve adayların marka kişilik özelliklerini belirlemek amacıyla her bir aday için doğrulayıcı faktör analizi yapılmıştır. Anket çalışması 1-30 Mart 2019 tarihleri arasında yapılmıştır. Toplam 607 kişi ile görüşülmüş ancak kararsız olan seçmenlere anket uygulanmıştır. Bunun sonucunda 387 anket uygulanmış, eksik ve hatalı doldurulan anketlerin elenmesi sonucu 316 anket değerlendirmeye alınmıştır. A aday için gerçekleştirilen doğrulayıcı faktör analizi sonuçları aşağıda gösterilmiştir;

Tablo 2. A Adayının Marka Kişilik Özellikleri Doğrulayıcı Faktör Analiz Sonuçları

\begin{tabular}{|c|c|c|c|}
\hline $\begin{array}{l}\text { Model Uyum } \\
\text { İndeksleri }\end{array}$ & $\begin{array}{l}\text { Modifikasyon Öncesi } \\
\text { Model Uyum Değerleri }\end{array}$ & $\begin{array}{l}\text { Modifikasyon Sonrası } \\
\text { Model Uyum Değerleri }\end{array}$ & $\begin{array}{l}\text { Kabul Edilebilir } \\
\text { Uyum Değerleri }\end{array}$ \\
\hline Ki-Kare $\left(\chi^{2}\right)$ & 2367.232 & 582.277 & \\
\hline Serbestlik Derecesi (df) & 650 & 211 & \\
\hline$\left(\chi^{2}\right) / \mathrm{df}$ & 3.642 & 2.760 & $1-5$ \\
\hline $\mathrm{P}$ değeri & 0.000 & 0.000 & \\
\hline RMSEA & 0.092 & 0.075 & $0.05 \leq \mathrm{RMSEA} \leq 0.10$ \\
\hline RMR & 0.214 & 0.122 & $0.05 \leq \mathrm{RMR} \leq 0.10$ \\
\hline AGFI & 0.632 & 0.816 & $0.85 \leq \mathrm{AGFI} \leq 0.90$ \\
\hline NFI & 0.651 & 0.846 & $0.90 \leq \mathrm{NFI} \leq 0.95$ \\
\hline CFI & 0.718 & 0.894 & $0.90 \leq \mathrm{CFI} \leq 0.97$ \\
\hline GFI & 0.677 & 0.859 & $0.90 \leq \mathrm{GFI} \leq 0.95$ \\
\hline IFI & 0.720 & 0.896 & $0.90 \leq \mathrm{IFI} \leq 0.95$ \\
\hline
\end{tabular}

Kaynak: Schermelleh-Engel, K., Moosbrugger, H. ve Müler, H. (2003). "Evaluating the Fit of Structural Equation Models: Tests of Significance and Descriptive Goodness-of-Fit Measures". Methods of Psychological Research, 8(2), 23-74.

Tabloda ölçeğin kabul edilmesi için kullanılan istatistiksel uyum indeksleri gösterilmektedir. Modifikasyon sonrasında $\chi^{2}$ / df oranı 2.760, Yaklaşık Hataların Ortalama Kare Kökü (RMSEA) değeri 0.075 olup kabul edilebilir uyum değerleri arasında yer almıştır. Normlaştırılmış (NFI) Uyum İndeksi 0.846 değer ile mükemmel uyum aralığındadır. Karşılaştırmalı Uyum İndeksi (CFI) 0.894 değeri ile mükemmel uyum düzeyindedir. Uyum İyiliği İndeksi (GFI) ve Düzeltilmiş Uyum İyiliği İndeksi (AGFI) 0.859 ve 0.816 değerlerini alarak mükemmel uyum değerlerine sahiptirler. Artırımlı Uyum İyiliği İndeksi (IFI) 0.896 değer ile mükemmel uyum düzeyindedir. Tüm uyum değerleri bir arada değerlendirildiğinde veri ve model arasındaki uyumun olduğunun gözlemlenmesi üzerine boyutlarda yer alan özelliklerin değerleri Tablo 3'de görüldüğü gibidir. 
Tablo 3. A Belediye Başkan Adayına Yönelik Marka Kişilik Boyutlarına Ait Özelliklerin Değerleri

\begin{tabular}{|c|c|c|c|c|}
\hline \multicolumn{5}{|l|}{$\begin{array}{l}\text { Marka Kişilik } \\
\text { Boyutları }\end{array}$} \\
\hline $\begin{array}{l}\text { Kendini Beğenmiş } \\
(\alpha=0.845)\end{array}$ & $\begin{array}{c}\text { Tahmini } \\
\text { Değer }\end{array}$ & S.E. & C.R & $\begin{array}{c}\text { Standardize } \\
\text { Edilmiş Katsayılar }\end{array}$ \\
\hline Sahtekâr & 1.000 & & & 0.640 \\
\hline Gösteriş meraklıs1 & .972 & .098 & 9.687 & 0.650 \\
\hline Vurdumduymaz & .969 & .101 & 10.255 & 0.699 \\
\hline İlgisiz & .907 & .100 & 9.088 & 0.607 \\
\hline Kibirli & 1.000 & .101 & 9.622 & 0.645 \\
\hline Kuruntulu & .948 & .099 & 9.784 & 0.658 \\
\hline Yapmacık & 1.000 & .104 & 9.840 & 0.663 \\
\hline \multicolumn{5}{|l|}{ Yetersiz $(\alpha=0.782)$} \\
\hline Sorumsuz & .927 & .067 & 13.835 & 0.762 \\
\hline Etkisiz & .796 & .071 & 11.209 & 0.633 \\
\hline Beceriksiz & 1.000 & & & 0.818 \\
\hline \multicolumn{5}{|l|}{ Yetenekli $(\alpha=0.747)$} \\
\hline Sağlam karakterli & 1.000 & .096 & 11.522 & 0.739 \\
\hline Lider & 1.000 & .094 & 10.795 & 0.685 \\
\hline Anlayışlı & 1.000 & & & 0.686 \\
\hline \multicolumn{5}{|l|}{$\begin{array}{l}\text { Heyecan Verici } \\
(\alpha=0.780\end{array}$} \\
\hline Çağdaş & 1.000 & & & 0.748 \\
\hline Modern & .854 & .080 & 10.698 & 0.601 \\
\hline Enerjik & .973 & .076 & 12.880 & 0.712 \\
\hline Azimli & .946 & .077 & 12.302 & 0.683 \\
\hline \multicolumn{5}{|l|}{ Samimi $(\alpha=0.812)$} \\
\hline Gerçekçi & 1.000 & & & 0.716 \\
\hline Candan & 1.000 & 0.79 & 13.382 & 0.803 \\
\hline Cana yakın & 1.000 & 0.87 & 12.670 & 0.758 \\
\hline Neşeli & .975 & 0.097 & 10.006 & 0.672 \\
\hline \multicolumn{5}{|l|}{ Kuvvetli ( $\alpha=0.647)$} \\
\hline Dürüst & 1.000 & & & 0.700 \\
\hline Gözü pek & .954 & 0.085 & 11.179 & 0.683 \\
\hline
\end{tabular}

Tablo 3'de görüldüğü üzere Doğrulayıcı Faktör Analiz sonucunda kendini beğenmiş, yetersiz, yetenekli, heyecan verici, samimi ve kuvvetli boyutlarının kabul edilebilir model uyum değerine sahip olmadığı görülmüştür. Sonuçlarına bakıldığında ilk olarak kendini beğenmiş boyutu içerisinde yer alan, "hilekâr" ve "burnu havada" özellikleri istatistiki açıdan uygun olmadığı için ölçekten çıkarılmıştır. Cronbach Alfa Güvenilirlik katsayı oranının 0.845 ile çok iyi seviyede olduğu görülmektedir Yetersiz boyutu içerisinde yer alan, "aciz" ve "dikkatsiz" özellikleri istatistiki açıdan uygun olmadığ 1 için çıkarılmıştır. Cronbach Alfa Güvenilirlik katsayı oranının 0.782 ile iyi seviyede olduğu görülmektedir. Yetenekli boyutu içerisinde yer alan, "işbirlikçi” istatistiki açıdan uygun olmadığ 1 için çıkarılmıştır. Cronbach Alfa Güvenilirlik katsayı oranının 0.747 ile iyi seviyede olduğu görülmektedir. Heyecan verici boyutu içerisinde yer alan, "heyecanlı", “özgür", “özgün” ve "mükemmel” özellikleri istatistiki açıdan uygun olmadığ 1 için çıkarılmıştır. Cronbach Alfa Güvenilirlik katsayı oranının 0.780 ile iyi seviyede olduğu görülmektedir. Samimi boyutu içerisinde yer alan, "mutlu” ve "erdemli" değişkenleri istatistiki açıdan 
uygun olmadığı için çıkarılmıştır. Cronbach Alfa Güvenilirlik katsayı oranının 0.812 ile çok iyi seviyede olduğu görülmektedir Son olarak Kuvvetli boyutu içerisinde yer alan, "korkusuz" ve "sağlam" özellikleri istatistiki açıdan uygun olmadığ 1 için çıkarılmıştır. Cronbach Alfa Güvenilirlik katsayı oranının 0.647 ile orta seviyede olduğu görülmektedir. Tablo 4'de B adayının doğrulayıcı faktör analizi sonuçları aşağıda gösterilmiştir;

Tablo 4. B Adayının Marka Kişilik Özellikleri Doğrulayıcı Faktör Analiz Sonuçları

\begin{tabular}{|l|c|c|c|}
\hline $\begin{array}{c}\text { Model Uyum } \\
\text { İndeksleri }\end{array}$ & $\begin{array}{c}\text { Modifikasyon Öncesi } \\
\text { Model Uyum Değerleri }\end{array}$ & $\begin{array}{c}\text { Modifikasyon Sonrası Model } \\
\text { Uyum Değerleri }\end{array}$ & $\begin{array}{c}\text { Kabul Edilebilir } \\
\text { Uyum Değerleri }\end{array}$ \\
\hline Ki-Kare $\left(\chi^{2}\right)$ & 1217.054 & 651.003 & \\
\hline $\begin{array}{l}\text { Serbestlik } \\
\text { Derecesi }(d f)\end{array}$ & 419 & 236 & $1-5$ \\
\hline$\left(\chi^{2}\right) /$ df & 2.905 & 2.758 & $0.05 \leq \mathrm{RMSEA} \leq$ \\
\hline P değeri & 0.000 & 0.000 & 0.10 \\
\hline RMSEA & 0.078 & 0.075 & $0.05 \leq \mathrm{RMR} \leq 0.10$ \\
\hline RMR & 0.140 & 0.127 & $0.85 \leq \mathrm{AGFI} \leq 0.90$ \\
\hline AGFI & 0.734 & 0.791 & $0.90 \leq \mathrm{NFI} \leq 0.95$ \\
\hline NFI & 0.719 & 0.796 & $0.90 \leq \mathrm{CFI} \leq 0.97$ \\
\hline CFI & 0.793 & 0.858 & $0.90 \leq \mathrm{GFI} \leq 0.95$ \\
\hline GFI & 0.775 & 0.836 & $0.90 \leq \mathrm{IFI} \leq 0.95$ \\
\hline IFI & 0.796 & 0.860 & \\
\hline
\end{tabular}

Tablo 4'de ölçeğin kabul edilmesi için kullanılan istatistiksel uyum indeksleri gösterilmektedir. Modifikasyon sonrasında $\chi^{2} / \mathrm{df}$ oranı 2.758, Yaklaşık Hataların Ortalama Kare Kökü (RMSEA) değeri 0.075 olup kabul edilebilir uyum değerleri arasında yer almıştır. Normlaştırılmış (NFI) Uyum İndeksi 0.796 değer ile mükemmel uyum aralığındadır. Karşılaştırmalı Uyum İndeksi (CFI) 0.858 değeri ile mükemmel uyum düzeyindedir. Uyum İyiliği İndeksi (GFI) ve Düzeltilmiş Uyum İyiliği İndeksi (AGFI) 0.836 ve 0.791 değerlerini alarak mükemmel uyum değerlerine sahiptirler. Artırımlı Uyum İyiliği İndeksi (IFI) 0.860 değer ile mükemmel uyum düzeyindedir. Tüm uyum değerleri bir arada değerlendirildiğinde veri ve model arasındaki uyumun olduğu gözlemlenmektedir.

B adayı ile ilgili yapılan modifikasyonlar sonrasında kalan boyutların ve bu boyutlara ait özellikleri değerleri Tablo 5'de gösterilmişstir. 
Tablo 5. B Belediye Başkan Adayına Yönelik Marka Kişilik Boyutlarına Ait Özelliklerin Değerleri

\begin{tabular}{|c|c|c|c|c|}
\hline \multicolumn{5}{|l|}{$\begin{array}{l}\text { Marka Kişilik } \\
\text { Boyutları }\end{array}$} \\
\hline $\begin{array}{l}\text { Kendini Beğenmiş } \\
(\alpha=0.784)\end{array}$ & $\begin{array}{l}\text { Tahmini } \\
\text { Değer }\end{array}$ & S.E. & C.R & $\begin{array}{c}\text { Standardize } \\
\text { Edilmiş Katsayılar }\end{array}$ \\
\hline Sahtekâr & .941 & .113 & 8.362 & 0.622 \\
\hline Hilekâr & .969 & .116 & 8.354 & 0.574 \\
\hline Gösteriş meraklıs1 & .940 & .112 & 8.394 & 0.648 \\
\hline Vurdumduymaz & 1.000 & .111 & 9.037 & 0.857 \\
\hline İlgisiz & .917 & .111 & 8.248 & 0.587 \\
\hline Kibirli & 1.000 & & & 0.588 \\
\hline \multicolumn{5}{|l|}{ Yetersiz $(\alpha=0.727)$} \\
\hline Beceriksiz & 1.000 & & & 0.681 \\
\hline Etkisiz & .928 & .098 & 9.419 & 0.623 \\
\hline Sorumsuz & 1.000 & .097 & 11.018 & 0.763 \\
\hline \multicolumn{5}{|l|}{ Yetenekli $(\alpha=0.751)$} \\
\hline Anlayışlı & 1.000 & & & 0.718 \\
\hline Lider & .965 & .094 & 10.261 & 0.688 \\
\hline Sağlam karakterli & 1.000 & .098 & 10.576 & 0.717 \\
\hline \multicolumn{5}{|l|}{$\begin{array}{l}\text { Heyecan Verici } \\
(\alpha=0.797)\end{array}$} \\
\hline Çağdaş & 1.000 & & & 0.618 \\
\hline Özgün & .959 & .106 & 9.035 & 0.588 \\
\hline Modern & 1.000 & .114 & 8.822 & 0.571 \\
\hline Heyecanl1 & 1.000 & .121 & 9.130 & 0.596 \\
\hline Enerjik & 1.000 & .119 & 10.755 & 0.736 \\
\hline Azimli & 1.000 & .122 & 10.238 & 0.689 \\
\hline \multicolumn{5}{|l|}{ Samimi $(\alpha=0.718)$} \\
\hline Neşeli & 1.000 & & & 0.571 \\
\hline Mutlu & 1.301 & .110 & 8.468 & 0.591 \\
\hline Candan & .934 & .136 & 9.576 & 0.708 \\
\hline Erdemli & 1.000 & .126 & 8.917 & 0.636 \\
\hline \multicolumn{5}{|l|}{ Kuvvetli $(\alpha=0.577)$} \\
\hline Erkeksi & 1.000 & & & 0.584 \\
\hline Gözü pek & 1.084 & .113 & 9.617 & 0.698 \\
\hline
\end{tabular}

Tablo 5'de görüldüğü üzere amaliz sonucunda kendini beğenmiş, yetersiz, yetenekli, heyecan verici, samimi ve kuvvetli boyutlarının kabul edilebilir model uyum değerine sahip olmadığ1 görülmüştür. Sonuçlarına bakıldığında ilk olarak kendini beğenmiş boyutu içerisinde yer alan, "kuruntulu" ve "yapmacık" özelliklerini istatistiki açıdan uygun olmadığı için çıkarılmıştır. Cronbach Alfa Güvenilirlik katsayı oranının 0.784 ile iyi seviyede olduğu görülmektedir. Yetersiz boyutu içerisinde yer alan, "aciz" özelliği istatistiki açıdan uygun olmadığı için çıkarılmıştır. Cronbach Alfa Güvenilirlik katsayı oranının 0.727 ile iyi seviyede olduğu görülmektedir. Yetenekli boyutu içerisinde yer alan, "bilgili" istatistiki açıdan uygun olmadığ 1 için çıkarılmıştır. Cronbach Alfa Güvenilirlik katsayı oranının 0.751 ile iyi seviyede olduğu görülmektedir. Heyecan verici boyutu içerisinde yer alan özelliklerin tümü istatistiki açıdan uygundur ve Cronbach Alfa Güvenilirlik katsayı oranının 0.797 ile iyi seviyede olduğu görülmektedir. Samimi boyutu içerisinde yer alan, "cana yakın" ve "gerçekçi” özellikleri istatistiki açıdan uygun olmadığı için çıkarılmıştır. Cronbach Alfa Güvenilirlik katsayı oranının 0.718 ile iyi seviyede 
olduğu görülmektedir. Son olarak Kuvvetli boyutu içerisinde yer alan, "dürüst" istatistiki açıdan uygun olmadığı için çıkarılmıştır. Cronbach Alfa Güvenilirlik katsayı oranının 0.577 ile düşük seviyede olduğu görülmektedir.

C adayının doğrulayıcı faktör analizi sonuçları aşağıdaki tabloda gösterilmiştir;

Tablo 6. C Adayının Marka Kişilik Özellikleri Doğrulayıcı Faktör Analiz Sonuçları

\begin{tabular}{|l|c|c|c|}
\hline $\begin{array}{c}\text { Model Uyum } \\
\text { Indeksleri }\end{array}$ & $\begin{array}{c}\text { Modifikasyon Öncesi } \\
\text { Model Uyum Değerleri }\end{array}$ & $\begin{array}{c}\text { Modifikasyon Sonrası } \\
\text { Model Uyum Değerleri }\end{array}$ & $\begin{array}{c}\text { Kabul Edilebilir } \\
\text { Uyum Değerleri }\end{array}$ \\
\hline Ki-Kare $\left(\chi^{2}\right)$ & 1453.203 & 187.443 & \\
\hline $\begin{array}{l}\text { Serbestlik } \\
\text { Derecesi }(d f)\end{array}$ & 512 & 88 & \\
\hline$\left(\chi^{2}\right) /$ df & 2.838 & 2.130 & $1-5$ \\
\hline P değeri & 0.000 & 0.000 & \\
\hline RMSEA & 0.076 & 0.060 & $0.05 \leq \mathrm{RMSEA} \leq 0.10$ \\
\hline RMR & 0.153 & 0.084 & $0.05 \leq \mathrm{RMR} \leq 0.10$ \\
\hline AGFI & 0.722 & 0.899 & $0.85 \leq \mathrm{AGFI} \leq 0.90$ \\
\hline NFI & 0.692 & 0.911 & $0.90 \leq \mathrm{NFI} \leq 0.95$ \\
\hline CFI & 0.774 & 0.950 & $0.90 \leq \mathrm{CFI} \leq 0.97$ \\
\hline GFI & 0.761 & 0.935 & $0.90 \leq \mathrm{GFI} \leq 0.95$ \\
\hline IFI & 0.776 & 0.950 & $0.90 \leq \mathrm{IFI} \leq 0.95$ \\
\hline
\end{tabular}

Tabloda ölçeğin kabul edilmesi için kullanılan istatistiksel uyum indeksleri gösterilmektedir. Modifikasyon sonrasında $\chi^{2} /$ df oranı 2.130, Yaklaşık Hataların Ortalama Kare Kökü (RMSEA) değeri 0.060 olup kabul edilebilir uyum değerleri arasında yer almıştır. Normlaştırılmış (NFI) Uyum İndeksi 0.911 değer ile mükemmel uyum aralığındadır. Karşılaştırmalı Uyum İndeksi (CFI) 0.950 değeri ile mükemmel uyum düzeyindedir. Uyum İyiliği İndeksi (GFI) ve Düzeltilmiş Uyum İyiliği İndeksi (AGFI) 0.935 ve 0.899 değerlerini alarak mükemmel uyum değerlerine sahiptirler. Artırımlı Uyum İyiliği İndeksi (IFI) 0.950 değer ile mükemmel uyum düzeyindedir. Tüm uyum değerleri bir arada değerlendirildiğinde veri ve model arasındaki uyumun olduğu gözlemlenmektedir.

C adayı ile ilgili yapılan modifikasyonlar sonrasında kalan boyutların ve bu boyutlara ait özellikleri değerleri Tablo 7'de gösterilmiştir. 
Tablo 7. C Belediye Başkan Adayına Yönelik Marka Kişilik Boyutlarına Ait Özelliklerin Değerleri

\begin{tabular}{|c|c|c|c|c|}
\hline $\begin{array}{l}\text { Marka Kişilik } \\
\text { Boyutları }\end{array}$ & & & & \\
\hline $\begin{array}{l}\text { Kendini Beğenmiş } \\
(\alpha=0.789)\end{array}$ & $\begin{array}{l}\text { Tahmini } \\
\text { Değer }\end{array}$ & S.E. & C.R & $\begin{array}{c}\text { Standardize Edilmiş } \\
\text { Katsayılar }\end{array}$ \\
\hline Sahtekâr & 1.000 & .111 & 10.779 & 0.843 \\
\hline Hilekâr & 1.000 & .119 & 10.553 & 0.780 \\
\hline Yapmacık & 1.000 & & & 0.631 \\
\hline \multicolumn{5}{|l|}{ Yetersiz $(\alpha=0.660)$} \\
\hline Beceriksiz & 1.000 & & & 0.675 \\
\hline Sorumsuz & 1.000 & .119 & 8.822 & 0.731 \\
\hline \multicolumn{5}{|l|}{ Yetenekli $(\alpha=0.693)$} \\
\hline Anlayışlı & 1.000 & & & 0.684 \\
\hline Lider & 1.000 & .099 & 11.695 & 0.774 \\
\hline \multicolumn{5}{|l|}{$\begin{array}{l}\text { Heyecan Verici } \\
(\alpha=0.744)\end{array}$} \\
\hline Çağdaş & 982 & .092 & 10.675 & 0.645 \\
\hline Özgün & 1.000 & .093 & 11.046 & 0.669 \\
\hline Enerjik & .911 & .092 & 9.849 & 0.592 \\
\hline Azimli & 1.000 & & & 0.688 \\
\hline \multicolumn{5}{|l|}{ Samimi $(\alpha=0.737)$} \\
\hline Cana yakın & 0.952 & .096 & 9.904 & 0.625 \\
\hline Gerçekçi & 1.000 & & & 0.648 \\
\hline Candan & 1.090 & .098 & 11.093 & 0.714 \\
\hline \multicolumn{5}{|l|}{ Kuvvetli $(\alpha=0.672)$} \\
\hline Dürüst & 1.000 & .104 & 10.513 & 0.741 \\
\hline Gözü pek & 1.000 & & & 0.682 \\
\hline
\end{tabular}

Yukarıdaki tabloda görüldüğü üzere kendini beğenmiş, yetersiz, yetenekli, heyecan verici, samimi ve kuvvetli boyutlarının kabul edilebilir uyum değerine sahip olmadığı görülmüştür. Sonuçlarına bakıldığında ilk olarak kendini beğenmiş boyutu içerisinde yer alan, "gösteriş meraklısı", "vurdumduymaz", "ilgisiz", "kibirli", "kuruntulu" ve "burnu havada" özellikleri istatistiki açıdan uygun olmadığı için ölçekten çıkartılmıştır. Cronbach Alfa Güvenilirlik katsayı oranının 0.789 ile iyi seviyede olduğu görülmektedir Yetersiz boyutu içerisinde yer alan, "aciz", "etkisiz" ve "dikkatsiz" özellikleri istatistiki açıdan uygun olmadığ 1 için çıkarılmıştır. Cronbach Alfa Güvenilirlik katsayı oranının 0.660 ile düşük seviyede olduğu görülmektedir. Yetenekli boyutu içerisinde yer alan, "işbirlikçi", "sağlam karakterli", "bilgili" özellikleri istatistiki açıdan uygun olmadığ 1 için çıkarılmıştır. Cronbach Alfa Güvenilirlik katsayı oranının 0.693 ile düşük seviyede olduğu görülmektedir. Heyecan verici boyutu içerisinde yer alan, "modern”, “özgür" ve "mükemmel” özellikleri istatistiki açıdan uygun olmadığı için çıkarılmıştır. Cronbach Alfa Güvenilirlik katsayı oranının 0.744 ile iyi seviyede olduğu görülmektedir. Samimi boyutu içerisinde yer alan, "neşeli", "erdemli" ve "mutlu" değişkenleri istatistiki açıdan uygun olmadığı için çıkarılmıştır. Cronbach Alfa Güvenilirlik katsayı oranının 0.737 ile iyi seviyede olduğu görülmektedir. Son olarak Kuvvetli boyutu içerisinde yer alan değişkenlerin tümü istatistiki açıdan uygundur ve Cronbach Alfa Güvenilirlik katsayı oranının 0.672 ile orta seviyede olduğu görülmektedir. D adayının doğrulayıcı faktör analizi sonuçları aşağıdaki tabloda gösterilmiştir; 
Tablo 8. D Adayının Marka Kişilik Özellikleri Doğrulayıcı Faktör Analiz Sonuçları

\begin{tabular}{|l|c|c|c|}
\hline $\begin{array}{c}\text { Model Uyum } \\
\text { İndeksleri }\end{array}$ & $\begin{array}{c}\text { Modifikasyon Öncesi } \\
\text { Model Uyum Değerleri }\end{array}$ & $\begin{array}{c}\text { Modifikasyon Sonrası } \\
\text { Model Uyum Değerleri }\end{array}$ & $\begin{array}{c}\text { Kabul Edilebilir } \\
\text { Uyum Değerleri }\end{array}$ \\
\hline Ki-Kare $\left(\chi^{2}\right)$ & 1236.127 & 265.333 & \\
\hline $\begin{array}{l}\text { Serbestlik } \\
\text { Derecesi }(\mathrm{df})\end{array}$ & 390 & 109 & \\
\hline$\left(\chi^{2}\right) / \mathrm{df}$ & & & $1-5$ \\
\hline P değeri & 3.170 & 2.434 & \\
\hline RMSEA & 0.000 & 0.000 & $0.05 \leq \mathrm{RMSEA} \leq 0.10$ \\
\hline RMR & 0.083 & 0.067 & $0.05 \leq \mathrm{RMR} \leq 0.10$ \\
\hline AGFI & 0.140 & 0.098 & $0.85 \leq \mathrm{AGFI} \leq 0.90$ \\
\hline NFI & 0.744 & 0.871 & $0.90 \leq \mathrm{NFI} \leq 0.95$ \\
\hline CFI & 0.722 & 0.883 & $0.90 \leq \mathrm{CFI} \leq 0.97$ \\
\hline GFI & 0.789 & 0.927 & $0.90 \leq \mathrm{GFI} \leq 0.95$ \\
\hline IFI & 0.785 & 0.908 & $0.90 \leq \mathrm{IFI} \leq 0.95$ \\
\hline
\end{tabular}

Tabloda ölçeğin kabul edilmesi için kullanılan istatistiksel uyum indeksleri gösterilmektedir. Modifikasyon sonrasında $\chi^{2} / \mathrm{df}$ oranı 2.434, Yaklaşık Hataların Ortalama Kare Kökü (RMSEA) değeri 0.067 olup kabul edilebilir uyum değerleri arasında yer almıştır. Normlaştırılmış (NFI) Uyum İndeksi 0.883 değer ile mükemmel uyum aralığındadır. Karşılaştırmalı Uyum İndeksi (CFI) 0.927 değeri ile mükemmel uyum düzeyindedir. Uyum İyiliği İndeksi (GFI) ve Düzeltilmiş Uyum İyiliği İndeksi (AGFI) 0.908 ve 0.871 değerlerini alarak mükemmel uyum değerlerine sahiptirler. Artırımlı Uyum İyiliği İndeksi (IFI) 0.928 değer ile mükemmel uyum düzeyindedir. Tüm uyum değerleri bir arada değerlendirildiğinde veri ve model arasındaki uyumun olduğu gözlemlenmektedir.

D adayı ile ilgili yapılan modifikasyonlar sonrasında kalan boyutların ve bu boyutlara ait özellikleri değerleri Tablo 9'de gösterilmiştir. 
Tablo 9. D Belediye Başkan Adayına Yönelik Marka Kişilik Boyutlarına Ait Özelliklerin Değerleri

\begin{tabular}{|c|c|c|c|c|}
\hline $\begin{array}{l}\text { Marka Kişilik } \\
\text { Boyutları }\end{array}$ & & & & \\
\hline $\begin{array}{l}\text { Kendini Beğenmiş } \\
(\alpha=0.679)\end{array}$ & $\begin{array}{l}\text { Tahmini } \\
\text { Değer }\end{array}$ & S.E. & C.R & $\begin{array}{c}\text { Standardize } \\
\text { Edilmiş Katsayılar }\end{array}$ \\
\hline Sahtekâr & .818 & .095 & 8.597 & 0.558 \\
\hline Gösteriş meraklısı & 1.000 & .098 & 10.410 & 0.696 \\
\hline Vurdumduymaz & 1.000 & & & 0.687 \\
\hline \multicolumn{5}{|l|}{ Yetersiz $(\alpha=0.730)$} \\
\hline Beceriksiz & 1.000 & .113 & 10.359 & 0.724 \\
\hline Sorumsuz & 1.000 & & & 0.652 \\
\hline Etkisiz & 1.000 & .116 & 10.124 & 0.701 \\
\hline \multicolumn{5}{|l|}{ Yetenekli $(\alpha=0.747)$} \\
\hline Sağlam karakterli & 1.000 & & & 0.658 \\
\hline Anlayışılı & 1.074 & .104 & 10.337 & 0.698 \\
\hline Lider & 1.179 & .107 & 11.056 & 0.764 \\
\hline \multicolumn{5}{|l|}{$\begin{array}{l}\text { Heyecan Verici } \\
(\alpha=0.759)\end{array}$} \\
\hline Özgün & 1.000 & & & 0.631 \\
\hline Modern & .995 & .099 & 10.042 & 0.646 \\
\hline Enerjik & 1.000 & .103 & 10.826 & 0.710 \\
\hline Azimli & 1.000 & .108 & 10.409 & 0.676 \\
\hline \multicolumn{5}{|l|}{ Samimi $(\alpha=0.804)$} \\
\hline Cana yakın & 1.000 & .090 & 11.942 & 0.747 \\
\hline Neşeli & 1.000 & .091 & 11.621 & 0.725 \\
\hline Candan & .910 & .082 & 11.039 & 0.685 \\
\hline Mutlu & 1.000 & & & 0.704 \\
\hline
\end{tabular}

Tablo 9'da görüldüğü üzere kendini beğenmiş, yetersiz, yetenekli, heyecan verici, samimi ve kuvvetli boyutlarının kabul edilebilir model uyum değerine sahip olmadığı görülmüştür. Sonuçlarına bakıldığında ilk olarak kendini beğenmiş boyutu içerisinde yer alan, "hilekâr", "ilgisiz", "kibirli", "kuruntulu" ve "yapmacık" özellikleri istatistiki açıdan uygun olmadığı için ölçekten çıkartılmıştır. Cronbach Alfa Güvenilirlik katsayı oranının 0.679 ile orta seviyede olduğu görülmektedir. Yetersiz boyutu içerisinde yer alan özelliklerin tümü istatistiki açıdan uygundur ve Cronbach Alfa Güvenilirlik katsayı oranının 0.730 ile iyi seviyede olduğu görülmektedir. Yetenekli boyutu içerisinde yer alan, "bilgili" özelliği istatistiki açıdan uygun olmadığ 1 için çıkarılmıştır. Cronbach Alfa Güvenilirlik katsayı oranının 0.747 ile iyi seviyede olduğu görülmektedir. Heyecan verici boyutu içerisinde yer alan, "heyecanlı", ve "çağdaş" istatistiki açıdan uygun olmadığ 1 için çıkarılmıştır. Cronbach Alfa Güvenilirlik katsayı oranının 0.759 ile iyi seviyede olduğu görülmektedir. Samimi boyutu içerisinde yer alan, "gerçekçi" özelliği istatistiki açıdan uygun olmadığı için çıkarılmıştır. Cronbach Alfa Güvenilirlik katsayı oranının 0.804 ile çok iyi seviyede olduğu görülmektedir. Son olarak Kuvvetli boyutu içerisinde yer alan özelliklerin tümü istatistiki açıdan uygun olmadığı için ölçekten çıkarılmıştır.

\section{Sonuç ve Değerlendirme}

$\mathrm{Bu}$ çalışmanın amacı, belediye başkanlığı adaylarının seçmen nezdindeki marka kişiliklerini belirlemektir. Marka değerine sahip olmak siyasiler için son derece önemli bir faktördür. Bu marka değerini, seçmenlerle kurdukları iletişim, kişilik özellikleri ve iletişim becerileri gibi iletişim stratejileri belirlemektedir. Belediye başkanlığı adaylarının marka kişilik analizlerine yönelik gerçekleştirilen bu çalışmada Türkiye Büyük Millet Meclisi’nde \%10 barajını aşıp koltuk sahibi olan dört siyasi partinin 
adayları incelenmiştir. Araştırmada adaylar 42 değişkenin yer aldığ Amerika Başkanlık Seçimi marka kişiliği ölçeğine göre değerlendirilmiş ve bu ifadelere göre ne şekilde algılandıkları ve seçmenin idealindeki başkan adayı algısı ölçülmüştür.

Araştırmada yer alan demografik bilgiler ile ilgili sonuçlar şekildedir; cevaplayıcıların büyük çoğunluğu bekâr erkeklerden oluşup 32-38 yaş aralığında ve eğitim düzeyleri lisedir. Meslek gurubunda ise cevaplayıcıların çoğunluğunu işçiler oluşturup gelir düzeyi 0-2000 TL arasındadır. Cevaplayıcıların siyasal katılım özelliklerine bakıldığında; vatandaşların oy kullanacağı, adayları takip ettiği ve seçimler için açıklanan projeleri bildiği gözlemlenmiştir. En son oy verdikleri siyasi parti Cumhuriyet Halk Partisi olup siyasi düşünceleri cumhuriyetçidir.

Marka kişilik ölçeğine göre, belediye başkan adaylarına yönelik algı ve tutumların sonuçları şu şekildedir: Cevaplayıcıların, "Kendini Beğenmiş" boyutunda yer alan değişkenlerin marka kişilik özelliğine sahip adaylar için vermiş olduğu yanıtlara göre; A adayının en yüksek değişkenleri, yapmacık, burnu havada ve sahtekâr; B adayının gösteriş meraklısı, yapmacık ve hilekâr olduğu gözlemlenmiştir. C adayının en yüksek değişkenlerine bakıldığında, yapmacık, gösteriş meraklısı, burnu havada olarak değerlendirilmiş olup D adayının ise, yapmacık, gösteriş meraklısı ve hilekâr olduğu tespit edilmiştir. Sonuçlara bakıldığında adayların seçmene güven vermediği anlaşılmaktadır. Adaylar seçmen nezdinde genel olarak samimiyetsiz, güvenilmez ve egoistlerdir.

Cevaplayıcıların, "Yetersiz" boyutunda yer alan değişkenlerin marka kişilik özelliğine sahip adaylar için vermiş olduğu yanıtlara göre; A adayının en yüksek değişkenleri, dikkatsiz, beceriksiz ve etkisiz olarak tespit edilmiştir. B adayının, beceriksiz, sorumsuz ve etkisiz olduğu; $\mathrm{C}$ adayı ise, dikkatsiz, beceriksiz ve sorumsuz olarak değerlendirilmiştir. D adayının ise en yüksek ortalamaya sahip değişkenleri, etkisiz, beceriksiz ve sorumsuz olduğu gözlemlenmiştir. Sonuçlardan, seçmenin hiçbir adaya iş becerileri anlamında güvenmediği ve genel anlamda adayların sorumsuz ve etkisiz olarak değerlendirildiği anlaşılmaktadır.

Cevaplayıcıların, "Yetenekli" boyutunda yer alan değişkenlerin marka kişilik özelliğine sahip adaylar için vermiş olduğu yanıtlara göre; A adayının en yüksek değişkenleri, sağlam karakterli, anlayışlı ve bilgili; B adayının, bilgili, anlayışlı ve sağlam karakterli olduğu; C adayının, anlayışlı, sağlam karakterli, bilgili ve D adayının ise, anlayışlı, lider ve bilgili olduğu tespit edilmiştir. Sonuçlara bakıldığında seçmen, adayların genel itibariyle iyi bir karaktere sahip ve bilgili olduklarını belirtmektedir.

Cevaplayıcıların, "Heyecan Verici" boyutunda yer alan değişkenlerin marka kişilik özelliğine sahip adaylar için vermiş olduğu yanıtlara göre; A adayının en yüksek değişkenleri, heyecanlı, enerjik ve azimli olup B adayının, heyecanlı, azimli ve enerjik olduğu görülmektedir. C adayı, modern, enerjik, azimli; D adayı ise, azimli ve enerjik, modern ve heyecanlı olarak değerlendirilmiştir. Cevaplayıcıların algı ve tutumuna göre, adayların çağdaş, modern ve genel olarak azimli oldukları ayrıca belediye başkanlığı için heyecan duydukları görülmektedir.

Cevaplayıcıların, "Samimi” boyutunda yer alan değişkenlerin marka kişilik özelliğine sahip adaylar için vermiş olduğu yanıtlara göre; A adayının en yüksek değişkenleri, mutlu, neşeli, cana yakın ve erdemli olarak tespit edilmiş olup B adayının, mutlu, neşeli ve erdemli olduğu gözlemlenmiştir. C adayı, mutlu, neşeli ve erdemli; D adayı ise, mutlu, neşeli ve cana yakın olarak değerlendirilmiştir. Sonuçlara göre, adaylar seçmenin gözünde erdem sahibi ve samimilerdir. Bununla birlikte adayların mutlu oldukları düşünülmektedir.

Cevaplayıcıların, "Kuvvetli” boyutunda yer alan değişkenlerin marka kişilik özelliğine sahip adaylar için vermiş olduğu yanıtlara göre; A adayının en yüksek değişkenleri, erkeksi, dürüst ve gözü pek olarak tespit edilmiştir. B adayı, erkeksi, gözü pek ve dürüst; C adayı, dürüst ve gözü pek olarak değerlendirilmiştir. D adayının en yüksek ortalamaya sahip değişkenleri ise, erkeksi, gözü pek ve dürüst değişkenleridir. Yine sonuçlara bakıldığında, adayların seçmen nezdinde samimi, dürüst ve maskülen kişilik özelliklerine sahip olduğu görülmektedir. Ayrıca seçmen tarafından adayların cesur olduğu algısı taşınmaktadır. 
Literatürdeki benzer çalışmalar incelendiğinde, özellikle yabancı literatürde siyasi parti ve liderlerin marka kişilikleri ile ilgili araştırmalar yapıldığı görülmüştür. Buna göre Decker (2015) yılında Amerika'da gerçekleştirdiği çalışmada Başkanlık'a aday olan liderlerin marka kişiliklerini analiz etmiştir. Sonuçlara bakıldığında; Amerika'da ki seçmenin marka kişiliğini, karar vermenin kısa yolu olarak gördüğünü belirtmiştir. ABD'de seçmen, adayları zekâ, gelişmişlik, samimiyet ve yeterlilik gibi kişilik özellikleri kapsamında değerlendirmiş olup adayın fiziksel özelliklerinden ziyade ülkeyi yönetip yönetemeyeceği konusunda emin olmak istemiştir. Bu nedenle yeterlilik ve yetenek son derece zaruridir. $\mathrm{Bu}$ çalışmada da benzer sonuçlara ulaşılmıştır. Ancak seçmen adaylardan yeteneğin ve yeterliliğin yanı sıra fiziksel görünümüne önem vermesini ve iyi bir dış görünüme sahip olmasını beklemektedir.

Guzman ve Sierra (2009) Meksika Başkanlık Seçimlerinde adayların marka kişiliklerini analiz etmişlerdir. Bu çalışma için Aaker (1997) ve Caprara vd. (2002) geliştirdikleri ölçekleri kullanmışlardır. Adayların marka kişilikleri beş boyut altında toplanmış olup bunlar; yetkinlik, empati, açıklık, uyumluluk ve cömertliktir. Ortaya çıkan bulgulara göre seçmen kararını verirken adayların imajını ve kimliğini göz önünde bulundurmaktadır. Bu çalışmada da benzer sonuçlara ulaşılmıştır. Seçmen, başkan olacak adaydan yetkinlik, sorunları anlayabilme, çözüm geliştirebilme ve dürüstlük beklemektedir ancak belediye başkan adayının yeterlilik, yetkinlik gibi kişilik özelliklerinin yanı sıra adayın fiziksel görünümüne de özen göstermesini beklediği tespit edilmiştir. Bu yönüyle de Guzman ve Sierra (2009)'nın çalışmasıyla örtüşmektedir. Araştırmada, adayların yeteneklerinin yanı sıra fiziksel görünümün de seçmen için önemli bir karar verme ölçütü olduğu belirtilmiştir.

Smith (2009) tarafından İngiltere'de gerçekleştirilen “İngiliz Politikasında Marka Kişiliğini Kavramsallaştırma ve Test Etme" adlı çalışmada hem kendisinin geliştirdiği hem de Aaker (1997)'in marka kişiliği ölçeklerini kullanmıştır. Çalışma geleneksel pazarlama ile siyasal pazarlama arasındaki farkları incelemektedir. Bulgulara göre en büyük fark Aaker (1997)'in geliştirmiş olduğu "dürüstlük" boyutunda çıkmıştır. Geleneksel pazarlamada dürüstlük ilkesi vazgeçilmez iken siyasal pazarlamada bu ilkenin geçerliliği yok denecek kadar azdır. Çünkü ticari pazarlamada dürüstlükten cayılması durumunda büyük kayıplar oluşabilirken siyasal pazarlamada her zaman ikinci bir şans vardır. Siyasal pazarlamanın, siyasi fikirlerin temelinde neyin yapılması gerektiği günün şartları belirlemektedir. Bunun yanında, çalışmada politikacılar söz konusu olduğu zaman dürüstlük her zaman sorgulanır olmuştur sonucuna varılmıştır. Bu çalışmada da ulaşılan bulgulara göre, seçmen çoğu zaman adayların hem sahtekâr, vurdumduymaz, beceriksiz kişilik özelliklerine sahip olduklarını belirtirken hem de lider ruhlu, samimi ve yetkinlik sahibi olduğunu belirtmişlerdir. Bu durum, seçmenin siyasi adayları günün şartlarına göre değerlendirdiği ve karar verme sürecinde kendi fikrine yakın olanı tercih ettiği olarak açıklanabilir.

Haji (2013) yapmış olduğu çalışmada Aaker'in (1997) geliştirdiği marka kişiliği başta olmak üzere tüm ölçeklerin sadece pozitif faktörlerle kapsama alındığını ancak bir markanın sergilediği kişilikte sadece pozitif değil negatif yönlerine de odaklanmak gerektiğini savunmuştur. Bu nedenle çalışmasında "Negatif Kişilik Ölçeği” geliştirmiştir. Haji yapmış olduğu bu çalışma sayesinde marka kişilik ölçeklerine daha kapsamlı bir ölçüm olanağı sağlamıştır. Negatif kişilik özelliklerinin yer aldığı bu ölçek sayesinde siyasi aktörler seçmenin duygu ve düşüncelerini daha net ve kapsamlı olarak anlayabilecektir. Bu yönüyle de bu çalışmaya katkı sağlaması beklenmektedir. Zira adaylara atfedilen olumsuz kişilik özelliklerinin altında yatan sebepler adayların seçmeni anlayabilmesi ve daha sağlıklı bir iletişim için olanak vermektedir.

Caprara vd. (2002) ise, yapmış olduğu çalışmada 3000 İtalyan seçmenin kişilik özellikleri ile politikacıların kişilik özelliklerini kıyaslamış ve seçmenlerin, seçim kampanyaları sırasında siyasi adayların kişilikleri konusunda basitleştirilmiş algıları geliştirdiğini belirtmiştir. Mevcut araştırmada, hem kişilik ve siyaset arasındaki ilişkinin, hem de politikacılar ve seçim kampanyalarının aralarındaki ilişki incelenmiştir. Buna göre halk seçim kampanyalarının ardından bile uzun süre boyunca seçmiş oldukları adayın kişilik özelliklerine dikkat etmektedir. Araştırmada seçmenler tarafından en dikkat edilen kişilik özellikleri ise; dinamik olmak, yeterlilik ve yetkinlik olarak sıralanmıştır. Ayrıca seçmenlerin kendilerini gösterme biçimleri (öz şema) ile siyasi tercihlerini temsil eden adayları değerlendirmek için kullandıkları şemalar arasındaki uyumlar da tespit edilen diğer ölçütlerdendir. Bu çalışmada da benzer sonuçlara 
ulaşılmıştır. Kişilik ve siyaset arasındaki ilişki odaklı bakıldığında, seçmen yetkinlik, yeterlilik gibi kişilik özelliklerinin yanı sıra adayın dinamik olması, iletişim becerilerini iyi kullanması ve siyasi ideolojisinin olmaması gerektiğini belirtmiştir.

Siyasal marka çalışmalarında, liderin veya adayın kişilik özelliklerinin tespiti, bu özelliklerin ön plana çıkarılması ve bu özelliklere göre seçmenin siyasi aktörü nasıl algıladı̆̆ı marka ve değer oluşturma süreci açısından zaruridir. Tüm bu sonuçlar göz önünde bulundurulduğunda seçmenin siyasi lider veya adaydan ilk olarak yetkinlik ve yeterlilik beklediği daha sonra ise samimiyet ve dürüstlük aradığı belirlenmiştir. Özellikle yerel seçimlerin söz konusu olduğu durumlarda seçmen her şeyden önce adaydan, kenti tanımasını, kalkınmanın sürekliliği için çalışmasını, kentin sorunları için çözüm üretmesini, kendisini anlamasını ve iletişim becerilerini iyi kullanmasını beklemektedir. Ancak bir siyasi aktörden veya belediye başkan adayından beklenen sadece sorunlara çözüm üretebilmesi değil aynı zamanda vatandaşa karşı samimi ve dürüst olmasıdır. Adayın seçmenle güvene dayalı bir ilişki kurması desteğini almak ve tercih edilmek anlamlarına gelmektedir. Çünkü siyasilerin öncelikli görevi seçmeni kendi ideolojisine ikna etmektir. Fakat bu araştırma gerçekleştirilirken seçmenin adayları çok da iyi tanımadığı ortaya çıkmıştır. Zira adaylara kişilik özellikleri atfedilirken hem negatif hem de pozitif değişkenler bir arada belirtilmiş ve oranları oldukça yüksek çıkmıştır. Bu çelişkiye sebep olan bir diğer unsur da seçmenin siyaset konusuna mesafeli oluşu ve siyasi fikrini saklaması gerektiği düşüncesidir. Bu nedenle belediye başkan adaylarına kişilik özellikleri atfedilmesi istenirken seçmenin çoğunlukla çekimser kaldığı ya da tamamen reddettiği saptanmıştır. Bu çalışmanın kaynağı olan ve Decker (2015)'in gerçekleştirdiği Amerika Başkanlık Seçiminde Adayların Marka Kişilikleri araştırmasında bütün adaylar için nokta atış1 analizler tespit edilirken bu çalışmada seçmenin çekimser tavrı ve adayı tanımayışı sebebiyle aynı kesin bulgulara ulaşılamamıştır.

Çalışmanın devamında, seçim süreçlerinde seçmenlerin ve siyasi aktörlerin karşılıklı olarak birbirlerini anlayabilecekleri bazı önerilere yer verilmektedir. Bir politikacının siyasi arenadaki başarısı güçlü bir marka oluşturma algısına bağladır. Zira seçmenin oy kullanma sürecinde en önemli kılavuzu, aday hakkındaki sezgileri ve algılarıdır. Marka kişiliği, siyasal pazarlama uygulayıcılarına, adayın ayırt edici özelliklerini ve niteliklerini vurgulayarak başkan adayının markasını kişiselleştirmek için bir araç ve yöntem sağlamaktadır. Güçlü bir markaya sahip olmak kişilik için çok önemlidir çünkü adayın kimliğini iletmekle beraber diğer rakiplerin seçmen zihnindeki zayıflıklarına odaklanır.

Amerika Başkanlık Sistemi marka kişilik ölçeği, veri analizi sürecinde uyaran olarak kullanılan dört başkan adayı için kullanılmış ve veriler modelin uygun olduğunu göstermiştir. Ancak gelecekteki araştırmalar modelin belediye başkanlığı seçimlerinde adaylar için uygun olduğunu doğrulaması açısından daha geniş örneklem büyüklüğüne sahip seçmenlerde test etmelidirler. Bu ölçek gelecek araştırmalarda sadece belediye başkanlığı adaylarında değil farklı örneğin; genel seçimlerdeki liderler için uygulanmalıdır. $\mathrm{Bu}$ model genel seçimlerde uygulandığında seçmenin parti liderlerini daha yakından tanıyacağından araştırmacıların daha net bulgulara ulaşması beklenmektedir. Gelecekteki araştırmalar, bu çalışmayı gelecek seçimlerde demografik özellikler, siyasi parti farklılıkları veya daha geniş bir örneklem ile inceleyerek literatürü çoğaltmalıdır. Ek araştırmalar, alt grupların (demografik özellikler, parti grupları vb.) siyasi parti tercihlerini veya karşı tarafın marka kişiliklerini tanımlarken olumsuz özellikleri kullanma olasılığının daha yüksek olup olmadığını değerlendirebilir.

$\mathrm{Bu}$ çalışma yalnızca gelecek araştırmacılar için değil aynı zamanda siyasi arenada bulunan liderler ve adaylar içinde yol gösterici olmalıdır. Gerçekleştirilen bu çalışmalar sayesinde seçmenin düşünceleri, beklenti ve talepleri belirlenebileceğinden izleyecekleri yolda belli bir program oluşturmalarına ve seçmenle bağ kurmalarına yardımcı olacaktır. Bu tür çalışmalar seçmen ile siyasilerin birbirlerini daha iyi anlamasını sağlayacak dolayısıyla güven esaslı bir ilişki kurulacaktır. Hem daha iyi bir iletişim için hem de literatürümüzün genişletilmesi için bu kapsamdaki araştırmalara yönelik teşvikler arttırılmalıdır. 


\section{Kaynakça}

Aaker, J.L. (1997). Dimensions of Brand Personality. Journal of Marketing research. 34: 347-356.

Aydoğan, B. (2007). Politik pazarlama ve politik pazarlama uygulamalarına yönelik eğilimler: Üniversite öğrencileri üzerine bir uygulama. Yüksek lisans tezi, Çukurova Üniversitesi, Adana.

Bayraktaroğlu, G. (2002). Geleneksel pazarlamada politik pazarlamanın yeri. Dokuz Eylül Üniversitesi Sosyal Bilimler Enstitüsü Dergisi, 3, 58-84.

Bilbil Karayel, E. ve Çelikkol, N. (2015). "Siyasette Markalaşmak: 2014 Cumhurbaşkanlığı Seçimi Adaylarının Siyasal Marka Olarak Konumlandırılmasının Analizi”, Marmara Üniversitesi Öneri Dergisi, 11 (43): 231-250.

Boyraz, E. (2012). Stratejik Siyaset Pazarlaması ve Siyaset Pazarının Bölümlendirilmesi Üzerine Bir Araştırma. (Yayınlanmamış Doktora Tezi). Kayseri: Erciyes Üniversitesi Sosyal Bilimler Enstitüsü.

Caprara, G. V., Barbaranelli, C., \& Zimbardo, P. G. (2002). When parsimony subdues distinctiveness: Simplified public perceptions of politicians' personality. Political Psychology, 23(1), 77-95.

De Landtsheer, D. V., ve Vertessen, D., (2008). "Political Impression Management: How Metaphors, Sound Bites, Appearance Effectiveness, and Personality Traits Win Elections", Belgium, Journal Of Political Marketing, 217-238.

Decker, A.R. (2015). Dimensions of American Presidential Candidate Brand Personality. PhD thesis, Alliant International University. San Diego.

Gardner, B.G and Levy, S.J.,(1955). The Product and the Brand, Harward Business Rewiew (33).

Guzmán, F., \& Sierra, V. (2009). A political candidate's brand image scale: Are political candidates brands? Journal of Brand Management, 17(3), 207-217.doi:10.1057/bm.2009.19.

Gürbüz, E. Ve İnal, M. E. (2004). Siyasal Pazarlama Stratejik Bir Yaklaşım. Ankara: Nobel Yayın Dağıtım.

Haji, I. (2013). Negative brand personality: The construct antecedents and outcome variables PhD thesis, Ashton University. Retrieved from http://eprints.aston.ac.uk/22445/

Keresteci, Z. (2006). Siyasal partilerin politik pazarlama uygulamaları ile bu uygulamaların seçmenler üzerindeki etkileri ve bir uygulama. Yüksek lisans tezi, Trakya Üniversitesi, Edirne.

Kotler, P., (2000). Marketing Management. The Millennium Edition, The United States Of America, Prentice Hall International Inc., 2000.

Kurtuldu, H. ve Kırkbir, F. (2005), Siyaset pazarlaması ve demografik özelliklerin parti seçimine etkileri, Pazarlama Dünyası Dergisi, 19(1), 58-61.

Küçükerdoğan, R. (2011). Siyasal İletişim Süreci, Parti Logoları ve Çağrışımlar, Thebrandage, İstanbul, ss. 68.

Külter, B. ve Polat, C. (2008). Genç seçmenler gözüyle siyasal ürün (siyasi lider) özellikleri: Ankara'daki üniversite öğrencileri üzerine bir çalışma. Uluslar Arası İnsan Bilimleri Dergisi, 1, 1-31.

Maarek, P., (1995), Political Marketing and Communication, London, John Libby.

Markham,V.,(1972). Planing The Corporate Reputation London:George Allen and Unwin. London, Allen and Unwin, 1972.

Mauser, Garry A, (1983), Political Marketing: An Approach to Campaign Strategy, New York, Praeger.

Özgüven, N. ve Demirtaş, M.C. (2012). Siyasal pazarlama uygulamaları açısından belediye başkanlarının web sitelerinin değerlendirilmesi. Niğde Üniversitesi İktisadi ve İdari Bilimler Fakültesi Dergisi, 2, 238-252. 
Özkan, N. (2014). Türkiye ve dünyadan örneklerle seçim kazandıran kampanyalar. İstanbul: Mediacat Kitapları.

Qualter, T.H., (1991), “Advertising and Democracy in the Mass Age”, Macmillan Publications, London.

Phipps, M., \& Govan J.B., \& Jevons C. (2010). "The Duality Of Political Brand Equity." European Journal Of Marketing, $44(\%)$.

Schermelleh-Engel, K., Moosbrugger, H. ve Müler, H. (2003). "Evaluating the Fit of Structural Equation Models: Tests of Significance and Descriptive Goodness-of-Fit Measures". Methods of Psychological Research, 8(2), 23-74.

Smith, G. (2009). Conceptionalizing and using brand personality in British politics. Journal of Political Marketing, 8(3), 209-232. doi:10.1080/15377850903044858

Tan, A. (2002). İlke ve Uygulamalarıyla Politik Pazarlama. 1.Basım, Papatya Yayıncılık, İstanbul.

Tek, Ö. B. (1999). Pazarlama ilkeleri Türkiye uygulamaları, İstanbul: Beta Yayınevi.

Toksarı, M. ve Dağcı, A. (2013). Seçmen Nezdinde Siyasal Partilerin Marka Değerinin Belirlenmesi: Kırıkkale Örneği. International Journal of Social Science, 6(3): 1355-1388.

Uztuğ, F. (1999). Siyasal Marka Seçim Kampanyaları ve Aday İmajı. Ankara: MediaCat Yayınları

Uztuğ, F. (2009). "Siyasal Marka Derken”, Thebrandage, İstanbul, s. 63.

Uztuğ, F. (2011) "İletişimin Gücü, Siyasette Olanaklar ve İmkansızlıklar”, Thebrandage, İstanbul.

Wang, X. ve Yang, Z. (2008) Does Country-of- Origin Matter in the Relationship Between Brand Personality and Purchase Intention in Emerging Economies? International Marketing Review. 25(4): 458-474.

Yüce, A. (2014). Politik Pazarlama. Ankara: Merdiven Yayınları.

Yüksel, M., (2010). Spor Örgütlerinde Marka İmajı Kavramına Genel Bir Bakış. İstanbul: Bahçeşehir Üniversitesi. 